\title{
DENK- EN DOEGROEPEN VOOR EEN DUURZAAM TOERISME IN HASSELT
}

\author{
BELEIDSVOORSTELLEN
}

Raf Sluismans en Patrick De Groote

Samenvatting:

Voorliggend rapport vormt het antwoord op de vraag vanuit Stad Hasselt (B) om een focusgroep samen te stellen en te begeleiden bij haar zoektocht naar voorstellen die tot stedelijke vernieuwing met betrekking tot het Toerismebeleid moeten leiden. Het betreft hier het verslag van een half jaar “Denk-en Doegroepen” en de voorstellen die eruit voort kwamen.

Dit onderzoek werd uitgevoerd door het Limburgs Universitair Centrum (B) met medewerking van MERIT, Universiteit Maastricht (NL). De auteur is werkzaam bij beide universiteiten. 
Inhoudstafel

1.1 Inleiding 1

1.2 Verantwoording 1

$\begin{array}{lr}\text { 1.3 Praktische aanpak en planning } & 2\end{array}$

1.4 De voorstellen 4

1.4.1 Samenvatting 4

1.4.1.1 Cultuur, horeca en winkelen 4

1.4.1.2 Verbondenheid tussen natuur en cultuur 5

1.4.1.3 Verhogen van mobiliteit 6

1.4.2 Opmerkingen $\quad 8$

1.4.3 Diepte-interviews en achtergrondinformatie $\quad 9$

1.4.3.1 Cultuur, horeca en winkelen $\quad 9$

a. (H)erkenningslabel 9

b. Nieuw forum 12

1.4.3.2 Verbondenheid tussen natuur en cultuur $\quad 15$

a. Wekelijks evenement 15

b. Stadsbrochures thuisbezorgd 17

c. Informatie en vorming 18

1.4.3.3 Verhogen van mobiliteit 20

a. P\&R-parkings 20

b. Scheurpanelen met stadsplannetjes $\quad 21$

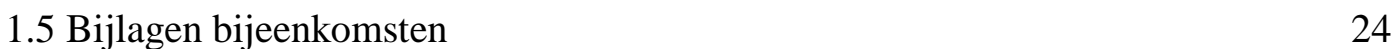

1.5.1 Uitnodigingsbrief 24

1.5.2 Verslag eerste bijeenkomst (4/4/2000) 25

1.5.3 Verslag tweede bijeenkomst (9/5/2000) 33

1.5.4 Verslag derde bijeenkomst (6/6/2000) 36

1.5.5 Verslag vierde bijeenkomst (4/7/2000) 41

1.5.6 Deelnemerslijst 44

1.6 Bijlagen $\quad 45$

1.6.1 Label: Voorbeeld Roskilde Stjernebutikker 45

1.6.2 Informatie en vorming: Voorbeeld Keulen Taxi-guide 50

1.6.3 Kaartensysteem: Voorbeeld Zweden, Chefen and Chefen 52

1.7 Bibliografie 53 


\section{Elk nieuw idee is dwaasheid tot het succes heeft.}

\section{Mark Twain}

\subsection{Inleiding}

Om te komen tot een duurzaam toerisme voor Hasselt, leek het aangewezen dat er continuiiteit geboden wordt aan de werkgroepen, opgericht in functie van het studieproject "Toerisme Hasselt 2000" (uitgevoerd in de periode 1996-1999). Bij de officiële voorstelling van het eindrapport "Toerisme Hasselt 2000", op 26 mei 1999 werd trouwens een dergelijke continuïteit ten zeerste aanbevolen.

In deel IV van het eindrapport "Denk- en Doe-groepen; een werkbenadering voor duurzame ontwikkeling in toerisme" werden er in vier werkgroepen negen beleidsprioriteiten ${ }^{1}$ naar voor gebracht met als doelstelling een duurzaam toerisme te bewerkstelligen. Duurzame ontwikkeling is, zoals de definitie omschrijft, die vorm van ontwikkeling die erin slaagt om een harmonie tot stand te brengen tussen economische, ecologische en socio-culturele belangen. Inherent aan het begrip 'ontwikkeling' is het feit dat hier niet gesproken kan worden van een eenmalig ingrijpen. Willen we komen tot een duurzaam toerisme voor Hasselt, dan is een verderzetting van het werk waarmee reeds begonnen werd, noodzakelijk.

\subsection{Verantwoording}

Enerzijds rekening houdend met het succes van de werkgroepen en de manier waarop de idee van de Denk- en Doe-benadering onthaald werd, anderzijds gezien de voordelen van dit opzet, werd ervoor gekozen om in dit nieuwe project een aangepaste, praktische werkwijze te hanteren. Waar er in Toerisme Hasselt 2000 in de werkgroepen vooral aandacht besteed werd aan het uitkristalliseren van negen beleidsprioriteiten en de

\footnotetext{
${ }^{1}$ 1. Leefbaarheid van de stad; 2 . Uitbouw van 'stad aan het water'; 3. Huidig patrimonium inventariseren, bewaren, respecteren en duurzaam toegankelijk maken; 4. Werkgroepen met actoren; 5. Mobiliteit via openbaar vervoer; 6. Fiets- en groene stad; 7. Combinatie cultuur/winkelen en horeca; 8. Verbondenheid tussen natuur en cultuur; 9. Diversiteit in winkel- en horeca-aanbod.
} 
invulling daarvan, hebben wij getracht om bij de continuering ervan een verdere concretisatie te geven aan de eerder gedane voorstellen.

Dit gebeurde door de nieuwe Denk- en Doe-groepen (die voor een gedeelte bestonden uit dezelfde mensen van Toerisme Hasselt 2000) op een begeleide en verantwoorde wijze te laten "werken" rond een aantal geselecteerde beleidsprioriteiten, gebaseerd op de oorspronkelijke negen beleidsprioriteiten (zie vootnoot 1) van de voormalige werkgroepen en de tien rubrieken van de strategische en praktische aanbevelingen $^{2}$ uit het eindrapport. Het is daarbij steeds onze bedoeling geweest om de verschillende actoren van toeristisch Hasselt te laten samenwerken opdat er voorstellen uitgewerkt zouden worden die het creëren van "het vakantiegevoel" bij de bezoeker betrachten. Meer bepaald, gingen we concreet aan de slag omtrent het optimaliseren en professionaliseren van duurzame samenwerkingsverbanden en synergieën. In samenspraak met de Schepen voor Toerisme en het diensthoofd voor Cultuur en Toerisme werd gekozen voor drie kernthema's, nl.:

- combinatie van cultuur, winkelen en horeca: meer samenwerking nastreven tussen middenstand, horeca, en de toerisme/cultuur-actoren

- verbondenheid tussen natuur en cultuur: uitwerken van, of bijdragen aan initiatieven waarbij telkens de link gelegd wordt tussen natuur en cultuur

- verhogen van mobiliteit: met aandacht voor het $P \& R$ systeem en de bereikbaarheid van de toeristische attracties en bewegwijzering.

\subsection{Praktische aanpak en planning}

Zoals eerder aangegeven streefden de Denk- en Doe- groepen naar het creëren van een vakantiegevoel bij de bezoekers van Hasselt. Belangrijke aspecten bij de concrete uitwerking van deze doelstelling is enerzijds het trachten realiseren van dwarsverbanden en/of samenwerkingsverbanden die moeten leiden tot een groei en kwalitatieve uitbouw

\footnotetext{
${ }^{2}$ 1. Leefbaarheid van de stad verbeteren; 2 . Uitbouw van 'Groene stad aan het water'; 3. Mobiliteit verhogen; 4. Valorisatie van het patrimonium; 5. Diversifiëren van het cultuur- horeca- en shoppingaanbod; 6. Diversifiëren van de toeristische vraag; 7. Informatie en communicatie; 8 . Imago-vorming; 9. Optimaliseren van samenwerkingsverbanden en synergieën; 10. Professionaliseren.
} 
van het toerisme. Anderzijds hebben we getracht een stukje van de diffuusheid, waardoor het toeristische aanbod gekenmerkt wordt, weg te werken door voorstellen helder en ondubbelzinnig uit te werken met daarbij steeds het oog op het economische belang ervan voor de verschillende stakeholders (belanghebbenden).

Meer in praktijk, liet de aanpak van de Denk- en Doe- groepen zich kenmerken door een hoog gehalte van remediëring dat, inherent aan de Denk- en Doe- benadering, steeds bottom-up was. Waar het ons om ging, was de werkgroep zelf aan de slag te laten gaan om, vertrekkend van datgene wat er al bestond in Hasselt, te komen tot een kwalitatief hoogstaander toeristisch aanbod. In dit hele proces, moet de taak van de projectbegeleiding dan ook voornamelijk gezien worden als faciliterend. De ondersteuning, geboden vanuit het Limburgs Universitair Centrum, had als doel te voorzien in de nodige theoretische en praktische informatie opdat de werkgroep haar taak naar behoren kon vervullen.

Naar de planning toe, werd gebruik gemaakt van een stappenplan dat er als volgt uitzag: (de verslagen van de diverse vergaderingen, evenals de deelnemerslijst, vindt $u$ in de bijlagen)

Stap 1: Plenaire bijeenkomst van de oude werkgroepen, aangevuld met nieuwe leden. (4 april 2000) Doel van deze eerste bijeenkomst is het opfrissen van de projectresultaten van "Toerisme Hasselt 2000" en het grondig verhelderen van de drie beleidsprioriteiten m.b.t. het nieuwe project. Na rondzending van het verslag van deze eerste bijeenkomst, was er een reactiemoment voorzien opdat groepsleden vragen en/of bemerkingen konden formuleren die aan het begin van volgende bijeenkomst besproken werden.

Stap 2: Denk- en Doe- sessie (9 mei 2000) met als doel te brainstormen over nieuwe ideeën met betrekking tot de vastgelegde beleidsprioriteiten.

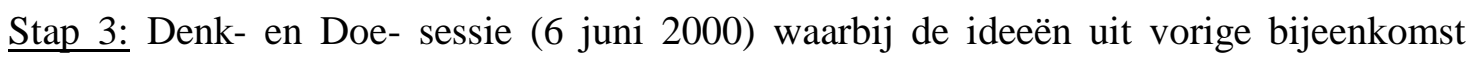
gestructureerd werden en aangevuld werden met een onderzoek op de haalbaarheid.

Stap 4: Denk- en Doe- sessie (4 juli 2000) met als doel het concretiseren van de gestructureerde ideeën en het formuleren van duurzame actiepunten. Aansluitend bij deze sessie was er een tweede reactiemoment voorzien opdat groepsleden, ditmaal op basis van het voorlopige eindrapport met strategische aanbevelingen voor toeristisch Hasselt, 
kritische vragen en/of bemerkingen konden formuleren die, op hun beurt, meegenomen werden in stap 5.

Stap 5: Afrondende Denk- en Doe- sessie (12 september 2000) met als doelstelling het voorlopige eindrapport te onderwerpen aan een kritische bespreking, rekening houdend met de toegestuurde opmerkingen. Op basis van deze sessie wordt het voorlopige rapport in zijn definitieve vorm gegoten.

Anders dan voorzien in het stappenplan, werd er na de vierde bijeenkomst geopteerd om een complementaire reeks diepte-interviews af te nemen van de 12 meest actieve participanten in de Denk- en Doe-groepen. Dit om niet enkel ons als projectbegeleiding, maar ook de betreffende personen, ervan te verzekeren dat ieders mening en kritische bedenkingen meegenomen zouden worden in het eindrapport.

\subsection{De voorstellen}

\subsubsection{Samenvatting.}

\subsubsection{Cultuur, horeca en winkelen.}

In relatie tot de combinatie van cultuur, horeca en winkelen kwam de Denk- en Doegroep tot het voorstel om voor de Hasseltse musea, bezienswaardigheden, horeca en winkels een label te ontwikkelen dat voor inwoners en bezoekers van Hasselt zichtbaar maakt welke specifieke Hasseltse kenmerken verkrijgbaar zijn op de betreffende lokaties. Dit label dient aanzien te worden als een marketinggerichte strategie met een tweeledig doel. Enerzijds is er de herkenbaarheid, anderzijds het verstrekken van informatie en het geven van een bepaalde erkenning. Het label op zich is dan ook eerder bedoeld als een (h)erkenningslabel; door in eerste instantie op de etalage te werken met een sticker die erop wijst dat de betreffende winkel of horeca-gelegenheid deelneemt aan de actie en tegelijkertijd erkend wordt voor datgene wat hij of zij te bieden heeft. In tweede instantie is er een pictogrammen-systeem dat op eenduidige wijze gebruikt wordt in de 
restaurantgids en heldere informatie verstrekt over welke van de typisch Hasseltse kenmerken te koop of verkrijgbaar zijn in het desbetreffende geval.

Het tweede voorstel, ook in relatie tot de combinatie tussen cultuur, horeca en middenstand is de oprichting van een nieuwe forum dat opgezet dient te worden als een ondersteuning voor de Dienst voor Toerisme en Cultuur. Aanbevolen wordt te starten met een vijftal mensen, met verschillende achtergronden in toeristisch en cultureel Hasselt, die geselecteerd worden op basis van hun reeds aangetoonde engagement voor Hasselt. Vertrekkende vanuit deze kleine kerngroep, die op occasionele basis samengeroepen wordt, met een vastgelegd minimum van twee keer per jaar, kan projectmatig gewerkt en gedacht worden. Idealiter wordt deze kerngroep gefaciliteerd door de stad Hasselt in vorm van een jaarlijkse toelage bestemd voor werkingskosten opdat deze mensen de mogelijkheid hebben ideeën te verkennen en de eerste aanzet te geven vooraleer er een daadwerkelijk initiatief opgezet wordt dat ter goedkeuring voorgelegd moet worden aan het College van Burgemeester en Schepenen.

\subsubsection{Verbondenheid tussen natuur en cultuur.}

Een eerste idee dat herhaaldelijk naar voor kwam tijdens de bijeenkomsten, was de organisatie van een evenement op of bij de Groene Boulevard waarbij zoveel mogelijk partijen betrokken moeten worden. Inhoudelijk werd hierin echter geen keuze gemaakt. Wel werd erop gewezen dat, gezien de reeds bestaande dichtheid aan evenementen tijdens de zomermaanden, een evenement met een wekelijks karakter voorkeur geniet. Men verwijst dan naar een verder uitbouwen van de antiekmarkt zoals die nu reeds op zaterdagvoormiddag plaatsvindt, en hoopt dat dit initiatief qua bekendheid en toeloop het succes van de antiekmarkt in Tongeren of de dierenmarkt in Mol zal halen.

Het tweede voorstel dat de verbondenheid tussen natuur en cultuur dient te bewerkstelligen, in overeenkomst met de aard van het eerste voorstel, vertrekt vanuit de opvatting dat men beter het reeds bestaande tracht optimaal te benutten alvorens men nieuwe dingen gaat uitwerken. Een blik in de brochures van Hasselt, leert ons dat er in en om Hasselt heel wat wandelingen en fietsroutes, al dan niet gericht op een centraal thema, beschikbaar zijn. Een oplossing voor de nog steeds te lage bezoekersfrequenties 
van de vele bestaande mogelijkheden, ook in relatie tot de verscheidene musea, kan volgens de Denk- en Doe-groep gevonden worden in het trachten mobiliseren van de 68.000 inwoners van Hasselt. Door bijvoorbeeld jaarlijks ieder gezin in Hasselt een toeristische brochure met daarin de verschillende wandelingen, fietsroutes, bezienswaardigheden en musea thuis te bezorgen, informeert men niet enkel de Hasselaren zelf, maar kan men hen ook aanwenden als ambassadeur voor de eigen stad. Als inwoners van Hasselt spelen zij een voortrekkersrol om de mond aan mond reclame een duwtje in de rug te geven. Het spreekt voor zich dat dit enkel mogelijk is wanneer ze over de juiste informatie beschikken.

Een derde voorstel waarbij de link gelegd kan worden tussen ditmaal de cultuur van bezoekers en de natuur [zowel letterlijk als figuurlijk] van Hasselt, komt voort uit de specifieke vraag van bezoekers die hier zijn voor hun werk. Steeds vaker worden taxichauffeurs geconfronteerd met de vraag van passagiers, die Hasselt om zakelijke redenen aandoen, om hen in maximaal één tot anderhalf uur langsheen de belangrijkste bezienswaardigheden te loodsen. Om dit werk op een voor beide partijen bevredigende manier te kunnen doen, zouden taxi-chauffeurs graag in het bezit zijn van enig houvast. Dit kan in de vorm van een speciaal voor hen geschreven boekje met een korte introductie bij ieder van de bezienswaardigheden enerzijds, maar anderzijds kan het ook in vorm van een aantal vormingsavonden per jaar. Verder redenerend op de vraag die taxi-chauffeurs krijgen, blijkt het ook zo te zijn dat stadswachten, politie-agenten en baliepersoneel vaak om inlichtingen verzocht wordt. Het spreekt voor zich dat ook zij doelgroep zijn voor dergelijke specifieke informatiebrochures en/of vormingsavonden. Volledigheidshalve dient vermeld te worden dat de stadswachten reeds dergelijke introductie (en rondleiding) krijgen bij hun aanstelling.

\subsubsection{Verhogen van mobiliteit.}

Ook hier kwam de Denk- en Doe- groep met een tweetal voorstellen. Het ene heeft betrekking op het optimaliseren van de werking van het Park and Ride-systeem, het tweede kan aanzien worden als een alternatief op een toeristische bewegwijzering, zij het met enkele surplussen. 
Wanneer we door de stad lopen, zien we nog steeds dat heel wat auto's fout geparkeerd staan terwijl een aantal van de grote P\&R-parkings haast leeg staan. Eén van de mogelijke oplossingen hiervoor is dat de politie en rijkswacht een strenger handhavingsbeleid voeren ten aanzien van foutparkeerders. Een andere oplossing is het duidelijk aangeven van de lokatie van de op- en afstapplaatsen van de gratis stadsbussen nabij de P\&R-parkings. Een derde mogelijkheid is het inrichten van sanitaire voorzieningen op deze terreinen die eigenlijk ook onveilig aandoen. De bewaking ervan is dus een vierde middel om het doel te bereiken. Waar het volgens de werkgroep eigenlijk om gaat, is niet zozeer het tekortschieten in elk van de vier voorgenoemde terreinen, maar wel een mentaliteitsprobleem bij de parkeerders. Een geïntegreerde aanpak lijkt aangewezen: door én het handhavingsbeleid op te voeren én de terreinen beter te infrastructureren én strenger toe te zien op de veiligheid van de auto's, wordt een stap in de goede richting gezet. Tevens is het belangrijk, dat wanneer dergelijke inspanningen geleverd worden, Hasselt daar voldoende ruchtbaarheid aan geeft hetzij in een informatiecampagne hetzij in de lokale, regionale of landelijke pers.

Tenslotte komen we bij het tweede voorstel inzake de mobiliteit. Zoals aangekondigd kan hier gesproken worden van een alternatief op een heringerichte toeristische bewegwijzering, zij het met enkele surplussen. Het voorstel bestaat erin, om net zoals dat in Scandinavië met het nodige succes aangewend wordt, op verscheidene plaatsen in en rond de stadskern panelen te zetten met daarop een soort (vandalismeveilige) metalen of plastic box waaruit passanten al dan niet tegen betaling een plattegrond kunnen nemen. Er zijn twee systemen op de markt: bij het ene steekt men een muntje in een automaat en krijgt men een plattegrond, bij het andere systeem kan men een kaartje van een scheurblok afscheuren. De onderliggende idee is dat bezoekers en soms zelfs inwoners onvoldoende de weg weten. Dit kan gaan van de weg naar algemene dingen zoals parkeerterreinen of het gemeentehuis tot een specifieke straat of een specifiek monument. Door bezoekers (veelal gratis), op verscheidene plaatsen in de stad, kaartjes ter beschikking te stellen, weet men als bezoeker ten alle tijde wat waar gelegen is. Bovendien kan een systeem uitgewerkt worden waarbij deze kaarten zelfbedruipend zijn doordat er advertentieruimte op te koop gesteld wordt. Anderzijds kan er op de achterzijde ruimte gereserveerd worden voor de Toeristische en Culturele diensten van 
Hasselt om aankomende evenementen aan te kondigen. Tevens kan op deze kaartjes, die op verschillende groottes kunnen gedrukt worden, het eerder voorgestelde labelsysteem uitgelegd worden voor mensen die nog niet helemaal weten hoe het in mekaar zit en welk pictogram waar precies voor staat.

\subsubsection{Opmerkingen.}

Alvorens de volgende paragraaf aan te vatten, zijn er twee punten die nog behandeld moeten worden. Het eerste punt is dat, wanneer we de hierboven genoemde voorstellen generaliseren, al snel duidelijk wordt dat vrijwel ieder voorstel sterke communicatieve aspecten omvat. Waar we het hadden over een Hasselts (h)erkenningslabel, werd dit voorgesteld als een herkenningspunt en een helder informatiesysteem. Toen het volgende voorstel werd besproken, nl. de oprichting van een nieuwe entiteit in Hasselt, had dit tot doel de communicatie tussen de verschillende belanghebbende partijen in Hasselt te bevorderen opdat er in de toekomst, op projectmatige basis, meer samengewerkt kan worden. Als derde suggestie werd als concrete actie het jaarlijks in de bus stoppen van een stadsgids genoemd. De dieperliggende gedachte voor deze actie is echter de overtuiging dat de Hasselaar zelf ambassadeur moet worden van zijn of haar stad. Een analoge gedachtengang gaat op voor de permanente vorming van taxi-chauffeurs, baliepersoneel, agenten, rijkswachters en stadswachten. Elk van deze partijen, die dagelijks in contact komen met toeristen, moet voorzien worden van de nodige bagage opdat ze antwoorden kunnen geven op de meest triviale maar ook specifieke vragen. Tenslotte hadden we het in het voorgaande over acties waarmee we hopen het hoofd te bieden aan het mentaliteitsprobleem dat veruitwendigd wordt in het foutparkeren en de P\&R-parkings die nog te weinig gebruikt worden. Hierbij wordt een sensibiliseringscampagne als belangrijk onderdeel aanzien. Het hoeft geen betoog dat communicatie de hoofdprioriteit is bij ieder van de hier genoemde voorstellen.

Als tweede punt dient vermeld te worden, dat hoewel de Denk- en Doegroep tijdens de eerste bijeenkomsten haar bezorgdheid uitte over het element natuur in haar breedste betekenis, het helaas niet kwam tot het formuleren van voorstellen die hun directe weerslag vinden in, of betrokkenheid uiten voor de natuur als zodanig. Anderzijds gaat hetzelfde op voor de toegankelijkheid van Hasselt voor gehandicapten. 


\subsubsection{Diepte-interviews en achtergrondinformatie.}

\subsubsection{Cultuur, horeca en winkelen.}

\section{a. (H)erkenningslabel}

Iedereen die met consumenten te maken krijgt, voelt steeds meer de algemene economische trend dat de consument alsmaar veeleisender wordt. Daarbij komt dat men door de enorme mogelijkheden van onze moderne tijd alsmaar meer ziet en hoort. Er is sprake van een zekere verzadiging onder consumenten wat maakt dat minimumstandaarden alsmaar hoger worden opgetrokken. Willen winkels, cafés, restauranthouders, hotels en musea hun cliënteel of bezoekers boeien, dan moeten ze komen met iets extra, met net dat ietsje meer. Bovendien moet de geboden meerwaarde ook nog makkelijk herkenbaar en toegankelijk zijn. W. Roovers stelt het in Recreatie en Toerisme ${ }^{3}$ als volgt: "De toeristische stad is een complete stad: een stad met een evenwichtig aanbod aan voorzieningen en sferen, met plekken voor alle gebruikers. De balans tussen de dynamiek van de samenstellende delen van het product stad (...) draagt bij aan de beschikbaarheid van voldoende ruimte voor alle groepen. (...) Het product stad moet zijn afgestemd op culturele en natuurlijke kwaliteiten, waarmee de stad zich onderscheidt (daar komt men voor!)." Het is net het toerisme dat volgens Roovers ${ }^{4}$ een stad meerwaarde geeft omdat, gezien het feit dat het gaat om een totaalbeeld waarbij verschillende partijen een rol spelen, meerdere partners verantwoordelijk zijn voor het 'samengesteld product' stad. Hiermee is de kous echter niet af aldus Roovers ${ }^{5}$, want de toeristische stad moet ook worden verkocht: "een eenduidige en herkenbare boodschap is de basis voor de promotie. Deze boodschap moet aansluiten bij de trots van de burgers: ook zij moeten zich erin herkennen en de boodschap willen uitdragen als een gastheer."

\footnotetext{
${ }^{3}$ W. Roovers: Recreatie en Toerisme, april 1999, pp 6-9

${ }^{4}$ idem

5 idem
} 
Redenerend vanuit gelijkaardige opvattingen, dat als men in een stad meerwaarde wil bieden, men moet komen met eenduidige en heldere informatie over het samengesteld product toerisme, stelt de Denk- en Doe- groep een (h)erkenningslabel voor. Het gaat hierbij om een bewuste keuze van de werkgroep om niet te kiezen voor een kwaliteitslabel. De grootste moeilijkheid bij het in leven roepen van een label, is immers het opstellen van de voorwaarden waaraan voldaan moet worden alvorens men het label toegekend krijgt. Idealiter moet de toekenning van het label door een onafhankelijke organisatie gebeuren en moeten er daarna regelmatige anonieme steekproeven gehouden worden om toe te zien op de naleving van de overeenkomst. Daarbij komt dat de voorwaarden voor de toekenning van het label op maat dienen te zijn voor de aard van de dienst die verleend wordt. Al snel wordt duidelijk dat wanneer men wil komen tot een kwaliteitslabel voor Hasselt, men een administratief apparaat in het leven moet roepen om het label te beheren. Kortom, men weet waar men begint maar niet waar men eindigt.

Een andere bedenking, die een aantal van de deelnemers in de Denk- en Doesessies maakten, is dat vrijwel iedere handelaar of horeca-uitbater het label zal willen dragen. Als het zo is, dat iemand van bijvoorbeeld de gespecialiseerde pers de proef op de som neemt bij een van de gelabelde etablissementen in Hasselt, en vervolgens om een of andere reden niet naar de, door het kwaliteitslabel aan zichzelf gestelde eisen behandeld wordt, wordt de naam van het volledige label door het slijk gehaald. Op zijn beurt resulteert dit erin dat iedere zichzelf respecterende horeca-uitbater zo snel mogelijk van het label af wil om niet geassocieerd te worden met minderwaardige kwaliteit. Wanneer dit gebeurt betekent dit bovendien een knauw voor de uitstraling van Hasselt als geheel.

Omwille van bovenstaande opvattingen, koos men voor een andere insteek voor een gelijkaardig voorstel, zij het (naar eigen woorden) minder elitair en met meer draagkracht. Vertrekkend vanuit de idee dat Hasselt een aantal eigenschappen van zichzelf moet promoten op een eenduidige en heldere manier, luidt het voorstel een (h)erkennings- of specialiteitenlabel op te richten. Het primaire doel van dit label is informatief te zijn naar de klanten/toeristen toe. Dit kan de vorm krijgen van een centraal logo dat op de etalage of naast de deur van de betreffende zaken geplaatst wordt en dat erop wijst dat ook deze zaak meedoet. Een mogelijkheid is dat er op dit logo ruimte is 
voorzien voor een aantal pictogrammetjes die op een herkenbare manier wijzen op de aanwezigheid van een of meer van de karakteristieke eigenschappen van Hasselt. Een andere mogelijkheid, is enerzijds te werken met het (h)erkenningslabel op de etalage, en vervolgens door middel van vermeldingen in een nieuwe rubriek van de restaurantgids, duidelijk maakt welke van de Hasseltse specialiteiten waar te verkrijgen zijn. Een gevolg van werken met de restaurantgids, is dat men deze gids zal moeten uitbreiden tot alle horeca-zaken. De werkgroep verkiest gebruik te maken van de tweede formule omdat men op deze manier, door het feit dat de restaurantgids regelmatig hernieuwd wordt, veel dynamischer kan tewerk gaan in het aanpassen van wie welk label draagt. Eens een label door middel van een sticker op een etalage hangt, is het moeilijk om het er weer af te halen wanneer de horeca-uitbater besluit zich niet langer te engageren. Met betrekking tot het engagement op zich, wordt het noodzakelijk geacht om het engagement te formaliseren in de vorm van een contract dat afgesloten wordt tussen de Stad Hasselt en het betreffende bedrijf. Op die manier worden zowel de rechten als de plichten van de betrokken partijen op eenduidige wijze vastgelegd. Ook de stad Roskilde in Denemarken werkt met een dergelijk herkenningslabel: winkels en horecazaken die het label dragen, noemt men "Stjernebutikker". In Denemarken gaat dit initiatief uit van de Kamer van Koophandel, die ook de controle uitoefent en een jaarlijkse contributie heft. Wanneer een winkel, café, hotel of restaurant wenst deel te nemen, ondertekent de zaakvoerder een contract voor een aantal jaren dat hem of haar ertoe verplicht aan bepaalde standaarden te voldoen. Gezien hier sprake is van een contract, zijn de bepalingen uit de overeenkomst ook juridisch afdwingbaar. Afdrukken van de internetpagina's waarop de betreffende bedrijven zich voorstellen, zijn onder bijlagen toegevoegd.

Waar het voor Hasselt echter op neer komt, is dat horeca-uitbaters of winkeliers zelf kunnen bepalen aan welke voor Hasselt kenmerkende eigenschappen zij wensen te voldoen. Voor het ene café kan dit betekenen dat het drie pictogrammetjes draagt: één voor de aanwezigheid van een soort Hasseltse jenever, een tweede voor de aanwezigheid van Hasseltse speculoos en de derde voor de aanwezigheid van een streekgastronomische specialiteit. Een ander café kan ook bijvoorbeeld drie pictogrammetjes dragen maar dan drie pictogrammetjes die wijzen op de aanwezigheid van drie soorten Hasseltse jenever. Waar het hier om gaat, is dat de pictogrammen gebaseerd zijn op specialisatie. Ook bij 
een specialiteitenlabel is het echter zo dat op regelmatige basis gecontroleerd zal moeten worden of aan de door de uitbaters aan zichzelf gestelde eisen voldaan wordt. De werkgroep stelt voor te beginnen met drie pictogrammen: een dat wijst op de aanwezigheid van Hasseltse jenever (vooraleer men de pictogrammen gaat toekennen, is het belangrijk dat eerst alle horeca-zaken aangeschreven worden via de Dienst voor Toerisme), een tweede dat wijst op de aanwezigheid van Hasseltse Speculoos (om dit onderdeel te laten slagen dient de Stad Hasselt eerst alle warme bakkers van Hasselt aan te schrijven; niet enkel om hen erbij te betrekken maar ook om hun kwalitatief advies over het product op zich), ten derde wil men een label voor streekgerechten (hiervoor kan men gebruik maken van de lijst van streekgastronomische specialiteiten die in de eerdere studie gemaakt werd, maar kan men ook aansluiting zoeken bij de Academie voor Streekgebonden Gastronomie). Bepaalde pictogrammen echter, zoals het pictogram dat wijst op toegankelijkheid voor rolstoelgebruikers, mogen uitbaters niet aan zichzelf toekennen. Hier wordt voorgesteld dat mensen uit de betreffende verenigingen zelf een controle uitvoeren in de bedrijven en dat zij vervolgens het pictogram al dan niet toekennen.

Het spreekt voor zich, dat wil dergelijk systeem ingeburgerd raken, er voldoende aandacht besteed moet worden aan de bekendmaking ervan. Een mogelijke oplossing hiervoor is de pictogrammen behalve in de restaurantgids (horecagids), ze ook op te nemen in de andere stadsgidsen of de toeristische brochures. Een andere mogelijkheid is aansluiting te zoeken bij een ander voorstel van de Denk- en Doe- groep, namelijk het voorstel van het scheursysteem met stadsplannen. Als het pictogrammensysteem hierop uitgelegd wordt, lopen bezoekers door de stad met als het ware de handleiding in de hand, en zullen ze geprikkeld worden om daadwerkelijk op zoek te gaan naar een etablissement dat het meest aansluit bij hun persoonlijke verwachtingen.

\section{b. Nieuw forum}

Volgens Prof. dr. Frank Go van de Erasmusuniversiteit doorloopt het toeristische aanbod een dynamisch proces van aanpassingen. Deze veranderingen gebeuren geleidelijk op basis van informele sociale contacten, daadwerkelijke overeenkomsten en 
samenwerkingsverbanden" ${ }^{6}$ Hij stelt bovendien: "De maatschappelijke- en marktveranderingen geven aanleiding tot behoefte aan een integrale aanpak, die op basis van interactie tussen gemeente, bewoners, bezoekers en bedrijven, de stedelijke visie en het organiserend vermogen actualiseert om slagvaardig op kansen in te spelen." ${ }^{7}$ Waar het om gaat volgens hem $^{8}$, is dat hoewel er reeds veel samengewerkt wordt, samenwerking die zich meestal louter beperkt tot de toeristische sector, de resultaten vaak toch eerder suboptimaal zijn. Samenwerking dient volgens Go meer gericht te worden op het zoeken van kansen en sterkten van steden samen met actoren uit het niettoeristische bedrijfsleven. Als voorbeeld verwijzen we graag naar de $\operatorname{TOBOS}^{9}$-studie uit 1995 die aan de hand van een tweetal case-studies beschrijft hoe de samenwerking tussen de toeristische overheid, het bedrijfsleven en het onderwijs kan en zou moeten verlopen.

De manier waarop men in de Denk- en Doe- sessies voorstelt om een actieve bijdrage te leveren aan het oplossen van het door prof. Go gestelde probleem luidt als volgt: zoals reeds aangegeven werd, wenst de werkgroep voor Hasselt de oprichting van een nieuw forum dat ten dienste staat van de dienst voor Toerisme en Cultuur. Belangrijk is dat er een kerngroep opgericht wordt, bestaande uit mensen die geselecteerd worden op basis van hun bewezen engagement voor het toerisme van Hasselt. Deze kerngroep, bestaande uit een vijftal personen, dient voornamelijk een antennefunctie te hebben om de toeristische productontwikkeling voor Hasselt een handje toe te steken. Vanwege die antennefunctie is het belangrijk dat deze nieuwe entiteit, die vorm kan krijgen onder eender welke naam, gepositioneerd wordt als ondersteuning van de bestaande dienst voor Toerisme en Cultuur. De groep kan samengeroepen worden op occassionele basis om nieuwe projecten op te zetten, die liefst zowel sectorverbindend als sectoroverschrijdend zijn.

Belangrijke elementen volgens de Denk- en Doe- groep zijn dat er een groepje mensen samengesteld wordt die een verregaande interesse voor toerisme gemeenschappelijk hebben. Deze entiteit heeft noch de bedoeling een nieuwe organisatie te worden met alle institutionele gevolgen vandien, noch heeft het de bedoeling om reeds

\footnotetext{
${ }^{6}$ F. Go: Recreatie en Toerisme, juli/augustus 1999, pp 10-13

${ }^{7}$ idem

${ }^{8}$ idem

${ }^{9}$ P. Boerjan, en S. Kochanek: Relatie tussen Cultuur en Toerisme, 1995
} 
bestaande organisaties te gaan overkoepelen. Het verleden wees immers uit dat samenwerking binnen bepaalde verenigingen op zich geen sinecure was. Vandaar dat in ons geval gekozen wordt voor een klein aantal mensen die elk hun antenne uitzetten en in de gelegenheid gesteld worden te leren en te kijken naar anderen. Daarbij komt deze groep samen om nieuwe projecten of ideeën voor Hasselt te initiëren. Waar nodig kan de kerngroep andere mensen uitnodigen omwille van hun deskundigheid of engagement terzake. Vandaar dat de nieuwe entiteit gezien en georganiseerd moet worden als een aanspreekpunt waar een aantal mensen te vinden zijn die bereid zijn om samen te werken en initiatieven te lanceren. Door projectmatig te werken en de kerngroep waar nodig uit te breiden met andere betrokken in relatie tot de projecten, voorkomt men dat deze groep een sleur wordt waarin telkens hetzelfde grote aantal mensen aangesproken wordt met bovendien het risico makkelijk uit te deinen tot een praatgroep. Er zijn echter nog twee belangrijke opmerkingen. Enerzijds is het noodzakelijk dat iemand aangeduid wordt als leider of voorzitter van deze nieuwe entititeit. Deze persoon moet als rode draad fungeren doorheen dit project en zou in staat moeten zijn als spil te fungeren: hij of zij moet zowel kort bij de middenstand als bij de lokale bewoners staan. Anderzijds, en in relatie tot het eerste punt, is het belangrijk, dat wanneer men bezig is met de uitwerking van een bepaald initiatief, ook iemand die kan optreden als vertegenwoordiger van een wijk of buurt, hierin betrokken wordt. Op die manier kan men ook een draagvlak creëren bij de buurtbewoners, waar dit tot nogtoe vaak over het hoofd gezien werd. Om dit initiatief enige kans van slagen te geven, wordt het nodig gevonden om deze entiteit te faciliteren vanuit de stad, zij het na een aantal goede afspraken. Het gaat hier financieel niet om astronomische bedragen, maar om het groepje in de mogelijkheid te stellen om te leren van andere steden en om ideeën een eerste aanzet of vorm te geven alvorens ze in concrete projecten gegoten worden die door het College van Burgemeester en Schepenen goedgekeurd en gefinancierd kunnen worden. Het is de bedoeling dat de stad een aantal garanties geeft die mogelijk maken dat gemiddelde projecten met gemiddelde kosten uitgevoerd kunnen worden na een princiepsovereenkomst. Prof. dr. F. Go vat het als volgt samen: "Voor de implementatie van stedelijk toeristische evenementen [projecten] is een goede regie en coördinatie nodig. Effectieve samenwerking is essentieel. Hierbij treedt de projectorganisatie op als 'trekker' en zijn de verantwoordelijkheden van de 
betrokken partijen duidelijk afgebakend. Bijvoorbeeld op basis van kernvaardigheden. Het projectteam stuurt op hoofdlijnen en stuurt bij op resultaten en middelen, klantgericht werken en intern ondernemerschap. "10

Enerzijds houdend aan de overtuiging dat de Denk- en Doe- groep een aanbevelenswaardige vorm van overleg is als ondersteuning voor de Dienst voor Toerisme, met als taak nieuwe voorstellen uit te werken voor Hasselt; maar anderzijds ook gezien het hierboven genoemde voorstel, komen we tot een bijkomend voorstel. Daar het duidelijk is dat de hierboven beschreven manier van werken onze voorkeur geniet, en dat we te maken hebben gehad met een permanente doch te beperkte deelname, van de uitgenodigde actoren van toeristisch Hasselt, stellen we dan ook voor om de Denk- en Doe- groep, zoals die tot op heden bestaat, om te vormen of te laten opgaan in de voorgestelde nieuwe entiteit. Vertrekkend met een harde kern van geëngageerde deelnemers, kan dan waar nodig op projectmatige basis een bijkomende tijdelijke werkgroep opgericht worden. Deze beperktheid in zowel omvang als tijd, kan bijdragen tot de succesvolle afhandeling van bepaalde initiatieven, zonder dat er sprake hoeft te zijn van een te langdurige belasting en een verwaterende belangstelling.

Een mogelijk alternatief, om dezelfde doelstellingen te bewerkstelligen, is één of twee keer per jaar een forum samen te roepen waarbij alle winkeleigenaars, horecauitbaters en museumdirecties uitgenodigd worden op een grootschalige bijeenkomst waarbij de Dienst voor Toerisme haar plannen voor de komende periode voorstelt. Op dat ogenblik krijgen de aanwezigen de gelegenheid om eventuele reacties te geven. Beide alternatieven worden opportuun geacht.

\subsubsection{Verbondenheid tussen natuur en cultuur.}

\section{a. wekelijks evenement}

Voor zover er bij dingen die een wekelijkse frequentie hebben, gesproken kan worden van een evenement, blijkt dat de Denk- en Doe- groep in relatie tot een evenement haar heil zoekt in een wekelijkse markt. Het gaat dan niet om de alledaagse markten waar

\footnotetext{
${ }^{10}$ F. Go: Recreatie en Toerisme, juli/augustus 1999, pp 10-13
} 
men om verse groenten en fruit gaat, maar om een markt die op termijn de allure zou moeten krijgen zoals de antiekmarkt van Tongeren, de dierenmarkt in Mol of de boekenmarkt van Damme. Gezien de stad recentelijk startte met een wekelijkse antieken brocantemarkt op zaterdagvoormiddag, tussen 8 en 13 uur, verkiest de Denk- en Doegroep deze markt aan te wenden als basis voor het wekelijkse evenement. Een nieuw evenement is alsdusdanig niet aan de orde.

Er zijn een aantal bevindingen onderliggend aan dit voorstel. Gezien de dichtheid aan evenementen die her en der in binnen- en buitenland georganiseerd worden, is er sprake van een zekere mate van verzadiging. Bovendien is de bezoeker, zoals eerder reeds werd vermeld, verwend, wat makkt dat wil men komen tot de succesvolle organisatie van een evenement, men moet excelleren. Men moet als organisatie van evenementen de naam die men reeds opgebouwd heeft ook kunnen blijven waarmaken zonder daarbij het risico te lopen een afkooksel te worden van initiatieven elders. Met betrekking tot het organiseren van evenementen is het belangrijk eerder kwaliteit na te streven dan kwantiteit. Daarbij komt dat Hasselt een prachtig heraangelegde Groene Boulevard en Kolonel Dusartplein heeft waar iedere week een antiek- en brocantemarkt georganiseerd wordt die op termijn zou kunnen uitgroeien tot de reeds eerder aangehaalde voorbeelden.

Wie echter wil scoren bij de organisatie van een al dan niet wekelijks terugkerend evenement, moet volgens Hein te Riele ${ }^{11}$ "hard en efficiënt werken, alert zijn, kennis hebben van hetgeen de concurrentie doet en moet bovenal oog hebben voor de bezoeker én de potentiële bezoeker. Een stad (...) moet vol zijn, moet uitdagen, inspireren en uitnodigen tot terugkomen." Wat de informatie van de concurrentie in Limburg betreft, liet het Provinciebestuur van Limburg onlangs een omvangrijke studie uitvoeren over markten in Limburg ${ }^{12}$. Zo staat er onder meer te lezen ${ }^{13}$ dat Limburg reeds 32 openbare markten telt over 27 gemeenten verdeeld. Het onderzoek wees uit dat een openbare markt voor haar minimale draagvlak, moet kunnen rekenen op de belangstelling van de lokale consumenten en de samenstelling van het reeds bestaande aanbod op de openbare markt. Belangrijke raadgeving is echter dat men moet opletten een "indigestie van openbare

\footnotetext{
${ }^{11}$ H. te Riele: Recreatie en Toerisme, februari 2000, p 9

${ }^{12}$ Provincie Limburg: 4de directie - cel middenstand: Markten in Limburg

${ }^{13}$ idem
} 
markten" te bekomen, daar dit de creativiteit en aantrekkelijkheid voor de consument

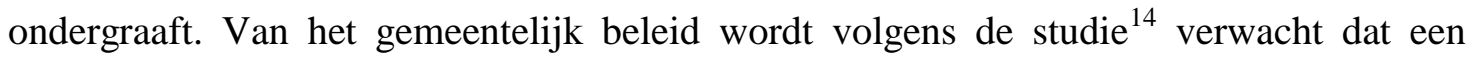
permanent overleg wordt opgezet met de uitbaters van de openbare markt waarin nagedacht wordt over de inhoudelijke positionering van de openbare markt, over de opstelling, het loopcircuit voor bezoekers enz. Daartegenover staat volgens de auteurs wel dat de economische betekenis van de openbare markt voor een gemeente niet zonder belang is. "De openbare markt kan een bijzondere bijdrage leveren aan de uitstraling van de gemeente in het algemeen en de kern in het bijzonder. Een goede openbare markt brengt sfeer en animatie en betekent een waardevolle aanvulling op het aanbod."15

Voor welk evenement er ook gekozen wordt, steeds zal een antwoord gevonden moeten worden op drie vragen ${ }^{16}$ :

1. Welke evenementen zijn voor onze gemeente wenselijk?

2. Waar zijn lacunes aanwezig in de organisatie van evenementen?

3. Hoe kan spreiding in onze gemeente vorm krijgen?

Zoals reeds aangehaald werd startte Hasselt met een wekelijkse antiek- en brocantemarkt op zaterdagvoormiddag tussen 8 en 13 uur. Waar de markt nu enkel op het Kolonel Dusartplein plaats vindt, hoopt men dat de markt een dergelijk succes kent, opdat er binnen enkele jaren sprake kan zijn van een antiek- en brocantemarkt op de volledige Groene Boulevard. Het is belangrijk dat dit initiatief een kans krijgt om uit te groeien tot iets groots, maar dat lukt niet zonder een blijvend engagement dat van twee kanten komt. De stad heeft reeds toegezegd tijd en middelen te investeren om dit project te laten slagen, nu ligt de bal echter in het kamp van de horecazaken op het Kolonel Dusartplein. Niet alle initiatief moet vanuit de stad komen. Wanneer men privaat met een goed voorstel komt, houdt de stad zich aanbevolen om haar steun te verlenen.

\section{b. stadsbrochures thuisbezorgd}

Over dit voorstel kunnen we redelijk kort zijn: "De toeristische stad komt tot stand in het samenspel tussen partijen die de stad maken en beheren: inwoners, bedrijven, eigenaren,

\footnotetext{
${ }_{15}^{14}$ Provincie Limburg: 4de directie - cel middenstand: Markten in Limburg

${ }^{15}$ idem

${ }^{16}$ A. Flikweert en L. Gorter: Recreatie en Toerisme, februari 2000, pp 14-15
} 
instellingen, belangengroepen én de overheid." 17 Waarom dan niet beginnen met de 68.000 inwoners van Hasselt trachten te gebruiken als personeel van de toeristische dienst als aanvulling op de 8 personen die er nu reeds werken? Vaak is het zo dat de inwoners van Hasselt niet weten wat er in hun stad te doen is, terwijl ook zij voor de toeristische bezienswaardigheden en evenementen een belangrijke doelgroep vormen. Een alternatief voor de thuisbezorging van de stadsbrochures kan zijn dat men in de stadsgids, die jaarlijks huis aan huis bezorgd wordt, een katern toevoegt. Anderzijds zou men hetzelfde kunnen doen met de Nieuwe Hasselaar, het krantje dat zes maal per jaar verspreid wordt. Ook de nieuwe website voor de Stad Hasselt, die momenteel in ontwikkeling is en die weldra gelanceerd wordt, biedt een alternatief om informatie aan de bevolking mede te delen. Het probleem waarmee men geconfronteerd wordt is niet zozeer dat de informatie niet beschikbaar is; het ligt er eerder aan dat men als stad steeds opnieuw, via alle mogelijke kanalen moet trachten de inwoners te sensibiliseren. Paul van Gessel van het Nederlands Bureau voor Toerisme is daar duidelijk in wanneer hij zegt ${ }^{18}$ "De eigen bevolking is de basis, die geven de stad zijn eigen kleur. De inwoners moeten als het ware toerist worden in de eigen stad en hun belevenissen overdragen op toeristen." Wat later, in hetzelfde artikel stelt hij" ${ }^{19}$ :De basis voor succes is om bewoners tot ambassadeur van de eigen stad te maken, ze te betrekken bij de plannen en ze informatie te geven."

\section{c. Informatie en vorming}

Het derde voorstel komt voort uit een zeer concrete vraag waar taxi-chauffeurs naar eigen zeggen bijna wekelijks mee geconfronteerd worden. Mensen die omwille van beroepsdoeleinden in Hasselt logeren, vragen regelmatig om in het laatste anderhalf uur alvorens ze naar de luchthaven gebracht moeten worden, even rondgereden te worden langsheen de belangrijkste bezienswaardigheden van Hasselt. Het vinden van de bezienswaardigheden op zich is uiteraard geen probleem voor de chauffeurs, maar het geven van achtergrondinformatie of de historiek van de bezienswaardigheden, ligt wat

\footnotetext{
${ }^{17}$ W. Roovers: Recreatie en Toerisme, april 1999, pp 6-9

${ }^{18}$ I. Schuitemaker: Recreatie en Toerisme, maart 2000, pp 6-9

${ }^{19}$ I. Schuitemaker: Recreatie en Toerisme, maart 2000, pp 6-9
} 
moeilijker. Daarbij komt dat dergelijke passagiers ook heel concrete vragen hebben over bijvoorbeeld hoeveel een gemiddelde Belg verdient, welke industrie er voornamelijk rond Hasselt gevestigd is enz. Om dit werk op een voor beide partijen bevredigende manier te kunnen doen, zouden taxi-chauffeurs zoals aangegeven graag in het bezit zijn van enig houvast. Hetzij in vorm van een speciaal voor hen geschreven boekje met een korte introductie bij ieder van de bezienswaardigheden, hetzij in vorm van een aantal vormingsavonden per jaar.

$\mathrm{Nu}$ blijkt echter dat niet enkel door de taxi-chauffeurs om informatie gevraagd wordt. Ook politieagenten, rijkswachters, stadswachten en baliepersoneel in hotels worden geconfronteerd met algemene en specifieke vragen. Voorbeelden zijn de locatie van openbare toiletten, de ligging van het stadhuis, de Dienst voor Toerisme, het Demermanneke en noem maar op. Ook zij zijn een doelgroep voor de vormingsavonden of het boekje dat speciaal voor dergelijke vragen geschreven kan worden. Het is uiteraard niet de bedoeling dat iedereen uit voorgenoemde beroepsgroepen opgeleid wordt tot een volwaardige gids: daar hebben ze de behoefte niet toe en dat is hun taak ook niet. Waar het wel toe bijdraagt is dat wanneer goed geinformeerde agenten en stadwachten bijvoorbeeld over straat lopen en dus ook antwoorden kunnen geven op de vragen van bezoekers, ze actief mee zorgen dat de bezoeker van Hasselt een positieve indruk heeft niet enkel van de stad maar ook van haar inwoners.

Het schrijven van dergelijk 'boekje voor informatieverstrekkers' hoeft niet veel geld en tijd te kosten. Een bescheiden brochure met daarin de nodige informatie volstaat. Iedere stadsgids of persoon die geïnteresseerd is in zijn of haar stad, zou in principe in staat moeten zijn om het boekje te schrijven. Een tweede idee is, dat net zoals de stadswachten bij hun aanstelling, ook taxi-chauffeurs en agenten regelmatig een begeleide toeristische wandeling maken door de stad. De stad zou dit kunnen formaliseren door bijvoorbeeld twee à drie keer per jaar een vormingsdag te organiseren waarop de personen uit die doelgroepen kunnen intekenen. Belangrijk is dat dergelijke initiatieven rechtstreeks naar de directie van hotels, commissarisen van rijkswacht en politie geventileerd worden, opdat zij hun personeel aanzetten tot het volgen van de vormingsdagen. De Denk- en Doegroep stelt voor een aantal "type-dagen" op te zetten zoals bijvoorbeeld een museumdag, een centrumdag, of busdag (Herkenrode en 
Bokrijk)... Tenslotte kan men de personen die de hele reeks vormingsdagen doorlopen hebben, belonen met een certificaat of enig ander teken van erkentelijkheid dat uitgereikt wordt tijdens een kleine receptie op het stadhuis. Dit laatste facet kan dan op zijn beurt zorgen voor wat extra publiciteit voor Hasselt in de dagbladen.

\subsubsection{Verhogen van mobiliteit.}

\section{a. P\&R-parkings}

Reeds vanaf de eerste vergadering stelde de Denk- en Doe- groep zich tot doel de werking van de P\&R-parkings (Slachthuiskaai, Grenslandhallen en Sporthal Alverberg) te optimaliseren. Even snel realiseerde de werkgroep dat dit geen gemakkelijke opgave is, aangezien we hier te maken hebben met een mentaliteitsprobleem. Vrijwel iedereen parkeert zijn wagen liefst net voor de etalage van de winkel waar hij of zij boodschappen moet gaan doen. Aangezien dit door de herinrichting van het stadscentrum niet meer mogelijk is, zoeken de meesten onder ons naar het beste alternatief: her en der verspreid op de stoepen. Iets dat een rol speelt op dit fenomeen, is de hoge prijs van de parkeertickets in de ondergrondse garages. Maar er is uiteraard meer. In de Denk- en Doe- sessies, maar ook tijdens de diepte-interviews werd duidelijk dat de P\&R-parkings op zich ook te wensen laten. Ze doen onveilig aan, er zijn geen sanitaire voorzieningen en het is op sommige terreinen onduidelijk waar precies op haltes zijn voor de stadslijnen. Op zich is iedereen tevreden met het initiatief van de gratis stadsbussen: men heeft nu de mogelijkheid om dingen centraal te organiseren waarbij mensen die op diverse locaties in de stad wonen, toch kunnen deelnemen omdat de bus tot net voor de deur rijdt.

Als we even in de andere richting redeneren en trachten de P\&R-parkings, waar die nog te weinig gebruikt worden, ook optimaal te benutten, dan zijn er een aantal oplossingen. Een eerste mogelijkheid is een strenger handhavingsbeleid te voeren naar foutparkeerders toe. Contact met het Belgisch Instituut voor VerkeersVeiligheid (BIVV) leert ons dat hierin positief effect bereikt kan worden door veel publiciteit te maken rond het toezicht dat opvallend uitgevoerd wordt. Daarbij moeten de controles onvoorspelbaar en moeilijk te omzeilen zijn, en liefst gebeuren op ogenblikken en plaatsen dat de kans 
om overtreders te betrappen groot is. Tenslotte moeten dergelijke acties lang aangehouden worden. Een bijkomend voordeel is dat de mensen door de grote dwang de gewoonte scheppen om gebruik te maken van de parkeerterreinen. Een bedenking die wel gemaakt moet worden alvorens met dergelijke acties te beginnen, is het feit dat ook foutparkeerders bezoekers van Hasselt zijn en dat een parkeerboete niet bijdraagt tot het positieve beeld van een stad. Een consequent parkeerbeleid daarintegen, dat voldoende gecommuniceerd wordt naar de inwoners en bezoekers, draagt wel bij aan een positieve indruk.

Een tweede actie die aangeraden wordt, samen met alle andere acties, is een sensibilseringscampagne te voeren naar de automobilisten toe. Ten derde moeten de P\&R-parkings beter uitgerust worden met sanitaire voorzieningen, een afsluiting en bewaking. Een actie die eerder betrekking heeft op de gewone betaalparkings, is niet langer per uur te betalen maar wel per minuut. Op die manier betaal je niet langer voor de rest van het uur waarop je vertrokken bent. Zoals reeds ten overvloede aangegeven, moet om een mentaliteitswijziging te bewerkstelligen een geïntegreerde aanpak nagestreefd worden: enkel door een combinatie van elk van de voorstellen hier genoemd in relatie tot de P\&R-parkings te realiseren, kan het meeste succes geboekt worden. Voorbeelden in eigen land vindt men o.m. in Antwerpen, Brugge en Gent. Hier maakt men respectievelijk gebruik van een parking op de Linkeroever, het stationsplein en Flanders Expo vanwaar men met de tram of stadsbusjes naar het centrum gebracht wordt. In aansluiting met de net aangehaalde voorbeelden, zou men in samenwerking met De Lijn kunnen spreken over de uitwerking van een toeristische shuttle voor Hasselt. De werkgroep denkt daarbij aan de sightseeing-bussen zoals men die in Londen maar ook Maastricht kent.

\section{b. Scheurpanelen met stadsplannetjes}

Als laatste voorstel, komen we tenslotte met het alternatief op een heringerichte toeristische bewegwijzering. Door op verscheidene plaatsen in en rond de stadskern van Hasselt de reeds geïntroduceerde solide panelen te plaatsen, met daarop een soort box waaruit je een plattegrond kan nemen of kopen, los je het probleem op van bezoekers die 
niet weten wat waar precies gelegen is. Er zijn twee systemen beschikbaar: bij het ene steekt men een muntje in een automaat en krijgt men een plattegrond, bij het andere systeem kan men een kaartje van een scheurblok afscheuren. In Scandinavië gebruikt men dit systeem sedert jaren, en is het zelfs zo ver geëvolueerd dat de kaartjes van de verschillende naast elkaar gelegen steden naadloos op elkaar aansluiten. Je kunt dus als het ware bijvoorbeeld naar Zweden op vakantie gaan zonder een landkaart te kopen. Het enige dat je moet doen wanneer je een stad nadert (en die liggen niet zo dicht bij elkaar als hier), is te stoppen bij de panelen en een gratis kaart te nemen. Op die manier kan je snel beslissen of de betreffende stad aansluit bij jouw persoonlijke behoeften en vervolgens de stad binnenrijden of passeren. Belangrijk is dat dergelijke panelen ook op verscheidene plaatsen in de stad verspreid staan. De Denk- en Doe- groep stelt voor om de panelen bijvoorbeeld als volgt te plaatsen: op de Grote Markt, aan de P\&R parkings Grenslandhallen en Kanaalkom, aan het Kolonel Dusartplein, aan het station, bij Herkenrode en op de grote parkings langs de autoweg nabij Hasselt. Om ze een aantrekkelijk uitzicht te geven enerzijds, maar anderzijds ook om bezoekers te lokken naar de diverse bezienswaardigheden, kan op de panelen een plattegrond afgedrukt staan met daar rondom een mozaïek aan foto's van de diverse bezienswaardigheden die op de kaart aangeduid staan. Hiermee komen we meteen bij het verschil tussen de hier voorgestelde plattegronden en de stadsplannen die nu reeds beschikbaar zijn langsheen de invalswegen. Gewone stadsplannen zijn niet toeristisch en geven alsdusdanig geen informatie over welke evenementen plaatsvinden in en om Hasselt, noch geven ze informatie over wat waar te zien is.

Om dergelijk initiatief op te zetten, zonder daarmee het stadspersoneel extra te belasten, kunnen contracten met privaatfirma's een oplossing zijn. We denken daarbij aan firma's die de bushokjes onderhouden. Een noodzakelijke voorwaarde om dit voorstel te laten slagen is dat de panelen steeds gevuld zijn, dat ze goed onderhouden en schoon zijn. Wat de financiering betreft, kan de stad een eenmalige inspanning doen om de panelen te plaatsen en kan de verdere uitbating en onderhoud overgelaten worden aan privaatfirma's. De kaartjes op zich kunnen zelfbedruipend zijn omdat je advertentieruimte te koop kunt aanbieden. Bovendien kan de stad in het algemeen of de Toeristische en Culturele diensten in het bijzonder, ruimte reserveren op de voor- of 
achterzijde van de plattegrondjes om eigen aankondigingen te doen. Waar het bij dit voorstel, net als bij een aantal van de vorige voorstellen om gaat, is de bezoeker te voorzien van informatie. Daarbij komt dat wanneer heldere en eenduidige informatie te verkrijgen is op plattegrondjes of bij stadswachten, taxi-chauffeurs, politieagenten of rijkswachters, dit in feite een besparing is op het personeel van de toeristische dienst betekent. Op die manier krijgen de acht mensen van de Dienst voor Toerisme meer tijd om de mensen die komen met vragen die een woordje meer uitleg vereisen, zoals bijvoorbeeld de vraag om een hotelkamer of gids te reserveren, te woord te staan. Uiteindelijk draait het er allemaal om de kwaliteit van het totale toeristisch product Hasselt te verhogen. 


\subsection{Bijlagen bijeenkomsten}

\subsubsection{Uitnodigingsbrief.}

Diepenbeek, 7 maart 2000

Geachte mevrouw, mijnheer,

Zoals beloofd op de officiële voorstelling van de onderzoeksresultaten van het project Toerisme Hasselt 2000 (26 mei 1999), willen we een continuïteit bieden aan datgene waarmee toen een begin werd gemaakt. Enerzijds rekening houdend met het succes van de werkgroepen en de manier waarop de idee van Denk- en Doe-benadering onthaald werd, anderzijds gezien de voordelen van dit opzet, willen we in het nieuwe project een aangepaste, praktische werkwijze hanteren. Waar er in Toerisme Hasselt 2000 in de werkgroepen vooral aandacht besteed werd aan het uitkristalliseren van negen beleidsprioriteiten, willen we nu, in de continuering, een verdere concrete invulling geven aan eerder gedane voorstellen.

Mogen we daarom, ook nu weer, rekenen op uw bereidwilligheid mee te werken aan het nieuwe project met als doelstelling concrete invulling te geven aan een duurzaam toerisme voor Hasselt. Het is dan ook niet voor niets dat de verderzetting van Toerisme Hasselt 2000 boven het doopfont gehouden werd als "3D-project Hasselt"; Denk- en Doe-groepen voor een Duurzaam Toerisme in Hasselt.

$\mathrm{Nu}$, wat is de concrete inhoud van uw engagement? De totale duur van het "3D-project Hasselt" omvat zes maanden, startend in maart, lopend tot 31 september 2000 (augustus wordt niet meegerekend). Tijdens die zes maanden, komt de Denk- en Doegroep een vijftal keren samen waarbij we concreet aan de slag gaan omtrent het optimaliseren en professionaliseren van duurzame samenwerkingsverbanden met betrekking tot drie domeinen. Ten eerste willen we komen tot een verbeterde combinatie van cultuur, winkelen en horeca, ten tweede willen we de verbondenheid tussen natuur en cultuur bewerkstelligen, tenslotte willen we nadenken over de mobiliteit en toegankelijkheid van Hasselt. Behalve uw aanwezigheid verlangen wij dat $\mathrm{u}$ twee keer eventuele vragen en/of opmerkingen formuleert naar aanleiding van een $u$ toegestuurd verslag, opdat we deze dan kunnen meenemen in een latere bijeenkomst. De eerste bijeenkomst, waarop we u bij deze van harte willen uitnodigen, is gepland op dinsdag 4 april van 18.00 tot 20.00 uur in lokaal F2 op de Universitaire Campus.

Samengevat kunnen we stellen dat het "3D-project Hasselt" er primair op gericht is te werken aan concrete en pasklare voorstellen die als doel hebben het toeristisch gamma van Hasselt kwalitatief te verbeteren door creatief aan de slag te gaan.

Een dergelijk project is echter gedoemd te mislukken zonder de bereidwillige medewerking van de betrokken partijen. Mogen we daarom eens te meer rekenen op uw engagement? Een duurzaam toerisme voor Hasselt gaat ook u aan.

Wilt u zo vriendelijk zijn even uw deelname aan het project en/of aanwezigheid op de eerste bijeenkomst te bevestigen via tel 011268752 of fax 0112687 60. E-mailen kan naar patrick.degroote@luc.ac.be of raf.sluismans@luc.ac.be

Met vriendelijke groeten, 


\subsubsection{Verslag eerste bijeenkomst.}

Diepenbeek, 5 april 2000

Geachte mevrouw, mijnheer,

Staat $\mathrm{u}$ mij toe $\mathrm{u}$ eerst en vooral hartelijk te bedanken voor uw deelname aan ons project "Denk- en Doegroepen voor een Duurzaam Toerisme in Hasselt". Het verheugt ons enorm te kunnen rekenen op uw deelname.

Zoals afgesproken op de eerste bijeenkomst, sturen we $u$ hierbij het verslag opdat $\mathrm{u}$ in de gelegenheid bent om achteraf, vanaf een wat grotere afstand, te reageren op de dingen die tijdens onze discussie naar voren kwamen. U hebt hiervoor de tijd tot en met maandag 24 april 2000. Mijn coördinaten vindt $u$ in het verslag.

Noteert $\mathrm{u}$ dat overeengekomen werd de volgende bijeenkomst te laten plaatshebben op dinsdag 9 mei aanstaande? We spreken af op de Universitaire Campus in lokaal F2. De vergadering zal, net zoals de eerste keer, van $18.00 \mathrm{u}$ tot $20.00 \mathrm{u}$ duren. We ontvangen $\mathrm{u}$ met broodjes en koffie.

Met vriendelijke groeten, en nogmaals bedankt voor uw welwillendheid.

Raf Sluismans 
Denk- en Doegroepen voor een Duurzaam toerisme in Hasselt.

Verslag eerste bijeenkomst: dinsdag 4 april 2000, 18.00u-20.05u

Aanwezigen:

- Zygmund Krzywania, Toerisme Hasselt

- Marc Volkaerts, Touristtram

- Sabine Maldoy, L.U.C.

- Michel Philtjens, Rederij Limburgia

- $\quad$ ? Philtjes, Rederij Limburgia

- Odette Buntinx, De Lijn Limburg

- Willy Smeets, Fietstoerisme Hasselt

- Jeanine Michiels, inwoonster binnenstad

- $\quad$ Eric Hox, Hasseltse Zelfstandige Ondernemers

- Paul Vos, Stedelijk domein Kiewit

- Marleen Devogelaere, Prov. Onderwijs, inwoonster

- $\quad$ Alida Vanholst, Herk en Mombeek

- René Geladé, Cultureel Centrum Hasselt

- Jos Vanlangenaeker, ETTC

- Sam Sluismans, onderzoeker Toerisme Hasselt 2000

- $\quad$ Marcel Vanreppelen, H.T.M.

- $\quad$ Patrick De Groote, Prof. L.U.C., inwoner

- Raf Sluismans, voorzitter denk- en doegroepen

\section{Verontschuldigd:}

- Claire Lelièvre, Japanse Tuin

- Lucas Bakx, Holiday Inn

- Ivo Konings, Toegankelijkheidsbureau

- Wim Gommers, Bibitor

- Jaak Vandeweyer, Trefcentrum Boulevard

- Ignace Schoepen, Natuurreservaten

- Walter van Soest, Limburg Toerisme

- Johan Swennen, Literair museum

- Jean-Pierre Swerts, Toerisme Hasselt

Volgende vergadering: dinsdag 9 mei

$18.00 u$ tot $20.00 \mathrm{u}$

Universitaire Campus, lokaal F2

Bemerking : Zoals uiteengezet op de eerste bijeenkomst, is er naar aanleiding van het eerste verslag een 'reactiemoment' voorzien. Het is de bedoeling dat jullie vragen en/of bemerkingen formuleren naar aanleiding van de eerste bijeenkomst en/of het eerste verslag, opdat we deze kunnen meenemen naar volgende bijeenkomst toe. Gelieve ons de opmerkingen schriftelijk, ten laatste op maandag 24 april 2000 te laten toekomen. U kunt mij e-mailen op raf.sluismans@luc.ac.be of r.sluismans@ merit.unimaas.nl Brieven kunt u sturen naar Raf Sluismans, Universitaire Campus gebouw D, B-3590 Diepenbeek, lokaal F11

Bijlage 1: $\quad$ Agenda eerste bijeenkomst

Bijlage 2: $\quad$ Kopie slides Toelichting Toerisme Hasselt 2000 en Toelichting Denk- en Doegroepen voor een Duurzaam toerisme in Hasselt

Bijlage 3: $\quad$ Verslag eerste brainstorm en afbakening van werkthema's 


\section{$\underline{\text { Denk- en Doe groepen voor een Duurzaam Toerisme in Hasselt }}$}

- Ontvangst met broodje en koffie

- Welkomstwoord door Prof. Dr. Patrick De Groote

- Voorstellen aanwezigen en controle coördinaten

- $\quad$ Toelichting Toerisme Hasselt 2000

․ kern, doel, eindresultaat

a conclusies

ㅁ voorwaarden verdere uitbouw en succes

$\square \quad$ strategische aanbevelingen

- Toelichting Denk- en Doe groepen voor een Duurzaam Toerisme in Hasselt

doel, belangrijke aspecten, praktische aanpak

ㄱinhoudelijke aanpak

ㄴ stappenplan en timing

- Koffiepauze

- Eerste aanzet tot brainstorm 


\section{Toerisme Hasselt 2000 (1996-1999)}

Kern: Analyse van aanbod- en vraagzijde van het Hasselts Toerisme

Doel: nastreven van een duurzame ontwikkeling door harmonie tussen economische, ecologische en socioculturele belangen.

Eindresultaat: strategische aanbevelingen ten behoeve van het Hasselts Beleid

Conclusies:

- Hasselt heeft daadwerkelijk een toeristisch product

- Hasselt heeft nog te weinig naambekendheid

- Hasselt heeft een gebrek aan eenduidigheid van het imago

- Hasselt heeft een groot toeristisch potentieel

Voorwaarden voor verdere uitbouw:

- Beleidsprioriteit geven aan toeristische uitbouw van Hasselt

- Meer financiële middelen ter beschikking stellen vanuit zowel overheden als privésector

- Bewustmaking van het economisch belang van de toeristische sector voor privésector

Voorwaarden voor succes:

- Geleidelijkheid

- Doelbewuste keuzes, gedragen door zoveel mogelijk actoren

- Samenwerking doorheen verschillende sectoren en beleidsniveaus

Strategische aanbevelingen:

- Leefbaarheid van de stad verbeteren

- Uitbouw van "Groene stad aan het water"

- Mobiliteit verhogen

- Valorisatie van het patrimonium

- Diversifiëren van het cultuur- horeca- en shoppingaanbod

- Diversifiëren van de toeristische vraag

- Informatie en communicatie

- Imago-vorming

- Optimaliseren van samenwerkingsverbanden en synergieën

- Professionaliseren

- Denk- en Doe- groepen voor een Duurzaam Toerisme in Hasselt

Doel:

Verdere concrete invulling geven aan de voorstellen gedaan in project “Toerisme Hasselt 2000" opdat er bij de bezoeker van Hasselt een "vakantiegevoel” gecreëerd wordt.

Belangrijke aspecten bij concrete uitwerking:

Dwarsverbanden en/of samenwerkingsverbanden realiseren met als einddoel groei en kwalitatieve uitbouw van het toerisme.

Wegwerken diffuusheid dat het toeristisch aanbod kenmerkt: voorstellen helder en ondubbelzinnig uitwerken en het economisch belang ervan aantonen.

Praktische aanpak:

Remediërend aan de slag gaan om zwakke en storende elementen van het toeristische aanbod weg te werken. 
Bottom-up aanpak: voorstellen uitwerken die ontsproten zijn aan de geest en samenwerking van de Denken Doe-groepen, samengesteld uit de verschillende actoren van het toeristisch product Hasselt.

\section{Concluderend:}

Primair gericht op het werken aan concrete en pasklare voorstellen met als doelstelling het toeristisch gamma van Hasselt kwalitatief te verbeteren door creatief aan de slag te gaan.

\section{Drie gekozen werkterreinen:}

\section{Mobiliteit verhogen}

Duidelijkere naderingspanelen

Verbeterde bewegwijzering

Openbaar vervoer stimuleren

P\& R systeem uitbouwen

Parkeeraanbod autocars verhogen

Laad- en losplaatsen voor autocars realiseren

Verbeteren connectiviteit binnenstad, omgeving

Uitbouwen fietsroutenetwerk

\section{Optimaliseren van samenwerkingsverbanden en synergieën}

Combinatie cultuur-winkelen: samenwerking tussen handelaars en toerisme/cultuur-actoren

Efficiëntere Hasseltse horeca-vereniging

Streekgastronomie commercialiseren

Groene buffer tussen Hasselt en Bokrijk

Samenwerking tussen Dienst voor Toerisme en Toerisme Limburg, Vlaanderen, Wallonië

Bipool Hasselt-Genk

Jenever en de industrie ervan

Mode en shopping

Congresbureau Hasselt-Genk en concurrenten en/of partners in de omgeving

\section{$\underline{3 \text { Verbondenheid tussen natuur en cultuur bewerkstelligen }}$}

Aandacht voor de Groene Boulevard

Concept van bezoekerscentra uitwerken

Ondersteuning van het Horta Cultura stedenproject

Netheid van de stad

Element water versterken

Plattelandstoerisme bewerkstelligen

Stappenplan:

Stap 1: Plenaire bijeenkomst oude werkgroepen, aangevuld met nieuwe leden. (begin april 2000)

Doel: opfrissen van projectresultaten en grondig verhelderen van de drie beleidsprioriteiten m.b.t. het nieuwe project.

Reactiemoment: Op basis van het verslag van de eerste bijeenkomst kunnen groepsleden vragen en bemerkingen formuleren, die aan het begin van volgende bijeenkomst besproken worden. (begin april 2000)

Stap 2: Bijeenkomst nieuwe D \& D groep. (1/2 mei 2000)

Doel: brainstorm over nieuwe ideeën met betrekking tot de prioriteiten.

Stap 3: Bijeenkomst D \& D groep. (eind mei 2000) 
Doel: structureren ideeën vorige bijeenkomst, aangevuld met onderzoek op haalbaarheid.

Stap 4: Bijeenkomst D \& D groep. (eind juni 2000)

Doel: concrete en duurzame actiepunten voorleggen en formuleren.

Reactiemoment: Na afronding voorlopig eindrapport, krijgen de D \& D groepsleden de tijd om vragen en bemerkingen te formuleren, die meegenomen worden in stap 5. (begin juli 2000)

Stap 5: Bijeenkomst D\& D groep. (begin september 2000)

Doel: kritische bespreking voorlopig eindrapport, rekening houdend met de geformuleerde opmerkingen.

Afsluiting: Publieke voorlegging eindrapport. (eind september 2000) 


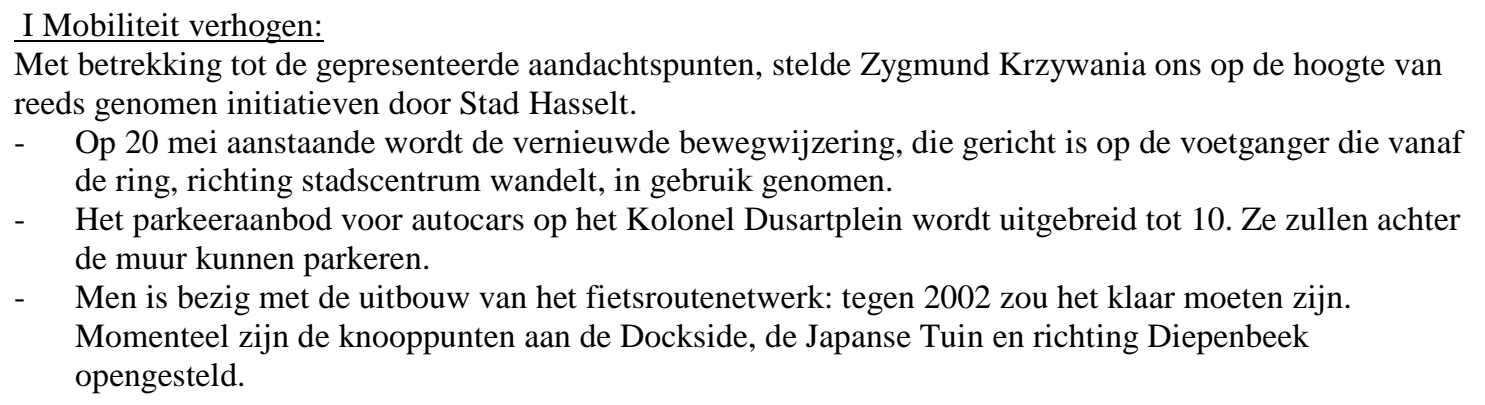

Met deze aandachtspunten in het achterhoofd begon de groep aan een brainstorm omtrent mobiliteit. Het gesprek handelde over vier thema's.

Ten eerste het probleem van de los- en laadplaatsen van autocars. Als men met gehandicapten en ouderen een trip maakt, zijn de voorziene parkeerplaatsen te ver gelegen. Men zou moeten komen tot de aanleg van meer laad- en losplaatsen, bijvoorbeeld aan iedere inham van de Kleine Ring.

Ten tweede is er het P \& R systeem dat nauwelijks werkt. De parking aan de Kanaalkom doet het goed, maar de parking aan de Grenslandhallen geeft een gevoel van onveiligheid en wordt daardoor weinig gebruikt. De vergadering komt tot de conclusie dat hier sprake is van van een mentaliteitsprobleem. In combinatie met een restrictief beleid ten aanzien van wild- en foutparkeerders zou hier een stap in de goede weg gezet kunnen worden.

Ten derde is de bewegwijzering naar het station weggevallen. Aan het station zou ook een bord gezet moeten worden die melding maakt van het feit dat het winkelcentrum zich op vijf minuten wandelafstand bevindt.

Ten vierde is er het feit dat er binnen de Kleine Ring nergens een plattegrond staat. Op de Grote Ring zijn ze wel nog aanwezig. Ook zouden er meer aanduidingen mogen zijn van de belangrijke attracties.

In acht genomen dat binnenkort nieuwe bewegwijzering voor voetgangers in gebruik genomen wordt, besluit de vergadering dat ze met betrekking tot het eerste thema mobiliteit, zich primair wil bezighouden met signalisatie. Hoewel men er zich bewust van is, dat mobiliteit een globaal probleem is, dat een geïntegreerde aanpak verdient, lijkt het ons verstandig om, met het oog op de haalbaarheid, ons te richten op de voor het toerisme relevante aspecten.

II Samenwerkingsverbanden en Synergieën bewerkstelligen:

Hoewel dit thema in eerste instantie niet veel weerklank vond, besloot de vergadering dat er ondermeer gewerkt kan worden aan de invulling van de Groene Boulevard. Met invulling wordt hier bedoeld het ontwikkelen van initiatieven die leiden tot wandelaars op de Groene Boulevard. In aansluiting met het nieuwe evenementenplein (Kolonel Dusartplein) moet hier zeker ruimte zijn om bijvoorbeeld boekenmarkten en dergelijke te laten plaatsvinden. Zygmund Krzywania maakte melding van een initiatief van de Stad Hasselt om binnenkort te starten met antiek- en brocantmarkten op het Kolonel Dusartplein. Het plaatsen van beelden op de Groene Boulevard wordt in dezelfde context vernoemd.

Een ander gespreksthema was de streekgastronomie. In samenspraak met de Hotelschool zou bijvoorbeeld aanzet gegeven kunnen worden tot themaweken of themaperiodes. Uitblijven van initiatieven zouden te wijten kunnen zijn aan hele praktische problemen zoals het onvoldoende beschikbaar zijn van receptuur. De horeca, die op de eerste bijeenkomst niet vertegenwoordigd was, zou hier een rol in moeten spelen. Men besluit om Jacques Collen uit te nodigen voor de volgende vergadering. Hij is voorzitter van de Academie voor Streekgebonden Gastronomie. In hoedanigheid van zijn functie, zou hij kunnen fungeren als klankbord voor mogelijke initiatieven en/of uitwerking van ideeën.

Concluderend kunnen we stellen dat er in relatie tot het thema samenwerkingsverbanden en synergieën geopteerd werd voor twee werkthema's; in eerste instantie het uitwerken van initiatieven die een invulling moeten geven aan de, door wandelaars, vrijwel niet bezochte Groene Boulevard. Ten tweede lijkt het opzetten van een initiatief dat te maken heeft met streekgastronomie erg interessant. 
III Verbondenheid tussen natuur en cultuur bewerkstelligen:

Ook hier kwam het gesprek al snel op het onderwerp van de Groene Boulevard. We zouden terug moeten kunnen komen tot eertijdse situatie waar "grootmoeders met hun pousette" op de Boulevard gingen wandelen. Ook hier is het zaak de Groene Boulevard een invulling te geven. De echtgenoot van mevr. Anita Moureau werd hier geopperd als interessante contactpersoon. Ook hij wordt op volgende bijeenkomst uitgenodigd.

In de binnenstad zelf zouden groene eilanden gevaloriseerd moeten worden. De vergadering denkt hierbij aan de tuin van het Gouvernement, aan het Leopoldplein, aan het Van Veldekeplein en het Begijnhof. Men stelde ook de vraag of initiatieven van de Denk- en Doegroepen zich dienen te beperken tot het bewerkstelligen van toerisme in de binnenstad. Daar dit niet het geval is, kwam mevrouw Vanholst met de idee om aandacht te besteden aan de wandelpaden in en om Hasselt.

Een laatste idee, dat net voor het afsluiten van de vergadering gelanceerd werd, is het beschikbaar maken van meer Bed and Breakfasts in en om Hasselt. Kunnen logeren bij mensen thuis, in het groen in de omgeving van Hasselt is uiteraard de verpersoonlijking van het bij elkaar brengen van natuur en lokale cultuur.

Recapitulerend werd omtrent het thema verbondenheid tussen natuur en cultuur, besloten om aandacht te besteden aan de wandelaar enerzijds, en Bed and Breakfast instellingen anderzijds; beiden zowel in als om Hasselt. 


\subsubsection{Verslag tweede bijeenkomst.}

Verslag tweede bijeenkomst denk- en doegroepen, dinsdag 9 mei 2000.

Agenda bijeenkomst:

- Welkom aan nieuwe leden denk- en doegroepen.

- Herhaling doelstelling project en beleidsprioriteiten.

- Samenvatting resultaten eerste bijeenkomst.

- Opmerkingen naar aanleiding van het eerste verslag;

- $\quad$ stad Hasselt,

- Tourist Tram,

- inwoonster binnenstad.

- $\quad$ Uiteenzetten doel deze bijeenkomst: concretiseren van de drie globale thema's naar aanleiding van:

- gastspreekster Miet Defillet van Toerisme Limburg over reglementering gastenverblijven,

- gegevens over wandelroutes uit de toeristische brochure van Hasselt,

- gegevens over organisatie van markten naar aanleiding van het onderzoek naar markten in Limburg, uitgevoerd door Provincie Limburg.

Volgende vergadering wordt gepland op dinsdag 6 juni 2000, van 18.00 tot 20.00 uur, in lokaal F2 op de Universitaire Campus in Diepenbeek.

Verontschuldigd:

$$
\begin{array}{ll}
\text { - } & \text { Mieke Broeders } \\
\text { - } & \text { Marleen Devogelaere } \\
\text { - } & \text { Inge Marchal } \\
\text { - } & \text { Philip Delvaux }
\end{array}
$$

Opmerking: tijdens deze bijeenkomst werd er niet gediscussieerd over de organisatie van een evenement in relatie tot de streekgastronomie. Ook hadden we het niet over de valorisatie van het groen in de Hasseltse binnenstad. Er werd overeengekomen, volgende bijeenkomst aan te vatten met deze aandachtspunten. 
Uiteenzetting door Miet Defillet.

Deel van haar taak bij Toerisme Limburg, is de begeleiding van startende uitbaters van Bed and Breakfast aanbieders.

Hoewel de meeste regio's met betrekking tot de uitbouw van gastenkamers een groei kennen, groeit Midden Limburg niet mee. Er werden reeds een aantal infodagen georganiseerd maar de administratieve vereisten, die bij de organisatie van dergelijke faciliteiten komen kijken, schrikken af. Het valt tegen toerisme te zien als de kip met het gouden ei.

Een aantal van de vereisten:

- Ten eerste moet gekeken worden naar de zones van de ruimtelijke ordening. Bed en Breakfasts, horen thuis in woon- en recreatiezones.

- Ten tweede moet er steeds een bouwvergunning aangevraagd worden wanneer er een andere functie gegeven wordt aan een woning (ook als je geen verbouwingen doorvoert). Dit hangt echter veel af van wat de stad eist.

- In principe zijn er geen wetten voor het verhuren van gastenkamers, mits je onder de vier kamers of onder de tien personen blijft. Wanneer men logies aanbiedt aan meer dan tien personen, of in meer dan vier kamers, is een hotelvergunning vereist. In deze situatie gaat echter weldra verandering komen: men is bezig met een vergunningsplicht, gebaseerd op de laagste categorie van hotels, voor iedereen die logies aanbiedt. Het doel is te voorzien in een overkoepeling vanaf Vlaams niveau om op die manier 1 promotiekanaal te creëren.

- Verder is inschrijving in het handelsregister verplicht voor iedereen die diensten levert: logies met ontbijt aanbieden wordt als dienst aanzien.

- Een BTW-nummer is vereist ongeacht de service die geleverd wordt: als je echter met het inkomen beneden de 225.000 BEF. per jaar blijft, is aangifte nodig maar volstaat een enkele boekhouding. Op logies, geldt een BTW-tarief van 6\%, op eten en drinken $21 \%$.

- Voor iedere gast die men ontvangt, moet er door de gast een politiefiche ingevuld worden, die de uitbater bij de politie moet inleveren.

- Jaarlijks wordt door de provincie belasting geïnd die gebruikt wordt voor de promotie van de logiesverstrekkers.

- Starters kunnen een subsidie krijgen die tot $40 \%$ van de verbouwingskosten terugbetaalt, met een maximum van 400.000 BEF per uitbater. Voorwaarde is dat er tien jaar lang gasten ontvangen worden, anders kan dit bedrag teruggevorderd worden.

In de omgeving van Hasselt-Diepenbeek, zijn een dertiental mensen geïnteresseerd in de uitbating van gastenkamers. Let wel, het gaat hier enkel om interesse, niet om starters. Bij Toerisme Limburg constateert 
men dat er een verband is tussen de fiestroutes en de vraag naar Bed- and Breakfasts. Kempen en Maasland, dat een beter uitgebouwd fietsroutenetwerk heeft, kent een grotere vraag naar B\&B's omdat gebruikers van het fietsroutenetwerk blijkbaar deze vorm van logies verkiezen. Verder redenerend op de vaststelling dat een beter uitgebouwd fietsroutenetwerk samen gaat met een grotere vraag aan B\&B faciliteiten, is het aangewezen eerst aandacht te besteden aan de uitbouw van het fietroutenetwerk omdat dit op zijn beurt een grotere vraag naar B\&B's met zich meebrengt. Wanneer er een grotere vraag is, zullen ook meer mensen geïnteresseerd zijn in het aanbieden van gastenkamers, omdat de bezettingsgraad dan hoger zal zijn.

Waar het in dit project om gaat, is voor een stuk deel te nemen aan de productontwikkeling voor Toeristisch Hasselt. Op die manier trachten we in een eerdere fase in te grijpen en op die manier een bijdrage te leveren aan de creatie van behoeften. Dit is in tegenstelling tot de meer traditionele manier van werken waar men het aanbod voor dingen waar er (nog) geen specifieke behoefte naar is, gaat vergroten. Als we de toeristen naar Hasselt kunnen krijgen, dan onstaan bepaalde behoeften waarin voorzien kan worden.

Deze vaststelling neemt echter niet weg dat er getracht kan worden een betere dienstverlening aan te bieden die vertrekt van het bestaande aanbod. De vergadering denkt daarbij aan het opzetten van een centraal bureau dat een overzicht heeft van de beschikbare hotelkamers om op die manier, mensen die in Hasselt op bezoek zijn, snel en eenvoudig een hotelkamer te kunnen aanbieden, in eender welke prijscategorie.

In relatie tot het tweede gespreksthema van de avond, de wandelaars, werd vastgesteld dat er reeds een groot aanbod aan wandelroutes beschikbaar is. Om die routes te promoten, zouden ze gegroepeerd moeten worden. Een andere vaststelling is dat het onderhoud van de routes nogal eens te wensen laat. Er was reeds een project waarbij iedere wandelroute een sport- of wandelclub als peter of meter heeft die meldt wanneer er bijkomend onderhoud vereist is. Dit project liep echter niet optimaal.

Terugkomend op het grote aanbod van de wandelroutes, lijkt het de vergadering dat we steeds op hetzelfde probleem uitkomen: de individuele toerist weet te weinig. De stad doet reeds wat ze kan, maar de toerist is verwend en verlangt steeds meer. Hij wil verrast worden. Het succes van een toeristische plaats, hangt af van de kwaliteit van het arrangement. We zouden met ons project moeten trachten meerwaarde te bieden aan de toeristen. Hierbij is de medewerking van de handelaars noodzakelijk. Hasselt moet zich onderscheiden om op die manier interessanter te zijn dan de andere steden. 


\subsubsection{Verslag derde bijeenkomst.}

Verslag derde bijeenkomst denk- en doegroepen, dinsdag 6 juni 2000.

Agenda bijeekomst :

- Toelichting Stap 3.

- Herhaling doelstelling project en beleidsprioriteiten.

- Samenvatting resultaten tweede bijeenkomst.

- Concretiseren van de ideeën, formuleren van voorstellen.

Volgende vergadering wordt gepland op dinsdag 4 juli 2000, van 18.00 tot 20.00 uur, in lokaal F2 op de Universitaire Campus in Diepenbeek.

Verontschuldigd :

- Caroline Lahou

- Sabine Maldoy

- Marleen Devogelaere

- Zygmund Krzywania

Opmerkingen of aanvullingen naar aanleiding van dit verslag zijn welkom.

U kunt ze richten aan :

Sluismans Raf

Universitaire Campus, Gebouw D

3590 Diepenbeek

raf.sluismans@luc.ac.be

r.sluismans@merit.unimaas.nl 
Het doel van de derde bijeenkomst is het concretiseren van de tot nogtoe voorgestelde ideeën en suggesties. De betrachting van de huidige vergadering is dan ook het formuleren van voorstellen in relatie tot de drie beleidsprioriteiten :

- Samenwerkingsverbanden en synergieën bewerkstelligen tussen cultuur, winkelen en horeca.

- Verbondenheid tussen natuur en cultuur bewerkstelligen.

- Mobiliteit en toegankelijkheid in en om Hasselt vergroten.

Terugkijkend naar de eerste twee bijeenkomsten werden volgende ideeën naar voor gebracht :

- m.b.t. samenwerkingsverbanden en synergieën werd gesproken over een streekgastronomisch evenement eventueel op of in relatie met de Groene Boulevard.

- m.b.t. de verbondenheid tussen natuur en cultuur werd gezegd dat er initiatief genomen moet worden naar de wandelaar toe waarbij beslist werd dat we ons heil moeten zoeken in de meerwaarde die geboden moet worden.

- $\quad$ m.b.t. mobiliteit blijkt dat het Hasseltse P\&R systeem niet overal werkt, veelal te wijten aan een mentaliteitsprobleem. Ook hier werd gefocused op de wandelaar die het vaak moeilijk heeft in Hasselt door de afwezigheid van borden met daarop plattegronden.

Het voorgaande samenvattend zijn er een aantal woorden die tijdens voorgaande bijeenkomsten steeds terugkeerden :

- wandelaar

- mentaliteit

- samenwerking

- bewegwijzering

- streekgastronomie

- Groene Boulevard

- Meerwaarde

Ons inziens blijkt dat er vooral structureel gewerkt moet worden; er moet een aanpak nagestreefd worden waarbij zoveel mogelijk partijen betrokken worden. 
Concreet leggen we de vergadering volgende voorstellen als discussiethema voor:

- m.b.t. samenwerkingsverbanden tussen cultuur, horeca en winkelen :

- een kwaliteitslabel voor de Hasseltse winkels, horeca, musea, al dan niet gekoppeld aan streekgastronomie

- een centrale overkoepelende vereniging die horeca, middenstand, toerisme en cultuur insluit

- m.b.t. de verbondenheid tussen natuur en cultuur :

- een geïntegreerde marketingaanpak voor Hasselt onder de vorm van een streekgastronomisch-, mode-, of cultureel evenement op of bij de Groene Boulevard waarbij de hele middenstand, horeca en musea betrokken worden

- m.b.t. het verhogen van mobiliteit :

- op verscheidene plaatsen in de stad plattegronden voorzien in vorm van een scheursysteem (naar Scandinavisch model) waar bezoekers van Hasselt zelf een kaart kunnen afscheuren

- het functioneren van het $\mathrm{P} \& \mathrm{R}$ systeem verbeteren door stiptere en regelmatigere transporten van en naar de stad

Discussie naar aanleiding van de voorstellen :

1. Hasselts label voor middenstand, horeca, cultuur en toerisme :

- De moeilijkheid bij het in leven roepen van een label is het opstellen van de voorwaarden waaraan voldaan moet worden alvorens men het label toegekend krijgt

- Tweede moeilijkheid is dat, wil men geïnteresseerden vinden, het directe (financiële) voordeel aangetoond moet worden

- Een goed initiatief moet een uitstraling bieden voor Hasselt als geheel

- Idealiter moet de toekenning van het label door een onafhankelijke organisatie gebeuren en moeten er regelmatig anonieme steekproeven gehouden worden om toe te zien op de naleving van de overeenkomst

- Een optie zijn de evaluatie- of klachtenformuliertjes (zoals je die vindt bij Pizza Hut en Mc Donalds) om constant toe te zien op de kwaliteit van het aanbod

- De voorwaarden voor de toekenning van het label dienen op maat te zijn voor de aard van de dienst die aangeboden wordt : voor horeca bijvoorbeeld in relatie tot streekgastronomie, voor musea en middenstand voorwaarden over de manier waarop men ontvangen wordt. Het spreekt voor zich dat gastvrijheid en vriendelijkheid minimumvoorwaarden zijn voor iedereen die deelneemt in dit initiatief. 
2. Overkoepelende vereniging:

- Er is nood aan één centrale vereniging waar handelaars, horeca, cultuur en toerisme samen rond de tafel zitten om overleg te plegen over de diverse acties die door elk van de deelnemers ondernomen worden. Op die manier kunnen bijvoorbeeld handelaars en horeca kortsluiten over wederzijdse initiatieven.

- $\quad$ Een idee kan zijn dat deze vereniging voorgezeten wordt door de schepen van middenstand en dat ze gefaciliteerd wordt door een vast bureau dat kan voorzien in permanentie.

- Het kan niet de bedoeling zijn dat dergelijk bureau of dergelijke vereniging een soort tweede dienst voor toerisme wordt: hoewel beiden hetzelfde doel nastreven, hebben ze ieder hun afzonderlijke taken. Het is ook niet zo dat individuele handelaars, verenigingen of horeca-mensen verantwoording komen afleggen voor hun beslissingen: het gaat erom dat er een constructief samenwerkingsverband komt waarbij er voordelen voor iedereen zijn.

3. Evenement :

- Het wordt als belangrijk aanzien dat er bij de organisatie van een evenement rekening gehouden wordt met senioren. Hoewel het aantal senioren in onze maatschappij alsmaar toeneemt, blijken slechts weinig organisatoren van evenementen het economisch potentieel van deze klantengroep in te zien.

- Tweede belangrijke punt is dat het evenement plaatsvindt over de volledige Groene Boulevard.

- Ten derde zou er één centraal thema gekozen moeten worden en moeten andere dingen daarop geënt worden. Op die manier krijgen we een groots evenement met vele aspecten, waarbij handelaars, horeca, cultuur en toerisme ook betrokken zijn.

- De vergadering denkt aan een Belle Epoque evenement. Een aantal jaren geleden bestond er reeds een evenement in die aard, misschien dat dit uitgebreid kan worden. De vergadering dacht aan een old-timer treffen op de Groene Boulevard, samen met een gigantische verkleedpartij, orkestjes op diverse plaatsen, paardemolens in de binnenstad... Ook reeds bestaande initiatieven zoals de net opgerichte brocantmarkt kunnen hierbij betrokken worden. Het ene mag het andere niet in de weg staan.

- Daarbij komt dat speciaal voor het evenement, dat eventueel meerdere dagen kan duren, specifieke arrangementen uitgewerkt worden door de horeca.

4. Optimaliseren van het $P \& R$ systeem.

- Een mentaliteitswijziging van de bezoeker kan in de hand gewerkt worden door foutparkeerders te laten verbaliseren.

- In combinatie van het optreden door de politie zouden de parkeerterreinen per minuut moeten rekenen i.p.v. per uur. Op die manier betaalt men de tijd dat men daadwerkelijk op het parkeerterrein staat, en daalt voor veel consumenten ook de prijs. 
- $\quad$ De P\&R terreinen zouden uitgerust moeten worden met sanitaire voorzieningen.

- De dienstregeling van en naar de parkeerterreinen moet stipter en regelmatiger.

5. Scheursysteem met plattegronden.

- In Zweden is het zo dat als men een stad nadert, er panelen langs de weg staan waaruit men een plattegrond kan scheuren.

- Deze kaartjes zijn op meerdere plaatsen te verkrijgen : voor Hasselt zou dit kunnen betekenen dat er één paneel op de grote markt staat en dat er een aantal panelen langs de grote invalswegen (P\&R parkings) staan.

- De kaartjes zijn gratis voor de gebruiker, op de achterkant kunnen handelaars adverteren.

- Ook voor de inwoner van Hasselt en omgeving lijkt dit een nuttig systeem omdat ook de bezienswaardigheden en musea op de kaartjes aangeduid staan. Op die manier kunnen misschien ook de inwonders van Hasselt verleid worden om eens een bezoek te brengen aan de musea en bezienswaardigheden van Hasselt.

- De panelen dienen vandalisme-veilig te zijn.

6. Opmerkingen :

- Een ons inziens belangrijke opmerking is dat ieder gezin dat in Hasselt woont een exemplaar van de toeristische brochure in de bus zou moeten krijgen. Zij weten vaak zelf niet wat er in Hasselt te doen is, terwijl net zij de eerste ambassadeurs van hun stad kunnen zijn.

- $\quad$ Er is vraag vanuit de taxi-chauffeurs naar een introductie in de bezienswaardigheden van Hasselt ; vaak hebben zij zakenmensen in de wagen die vragen om een korte rondrit door Hasselt langsheen de belangrijkste bezienswaardigheden. De taxi-chauffeurs zelf ervaren het vaak als moeilijk om in die vraag te kunnen voorzien : een stadsgidsje voor chauffeurs of een introductie in de belangrijkste bezienswaardigheden van Hasselt en nabije omgeving lijkt aangewezen.

Naar volgende bijeenkomst toe, wordt getracht om de voorstellen, die nu reeds wat concreter werden, in te bedden in praktijkvoorbeelden en concrete methodieken opdat we met het oog op onze vooropgestelde doelstellingen, nog meer kunnen concretiseren. 


\section{$\underline{\text { 1.5.5 Verslag vierde bijeenkomst. }}$}

Verslag vierde bijeenkomst denk- en doegroepen, dinsdag 4 juli 2000.

Agenda bijeenkomst :

- $\quad$ Toelichting stap 4.

- Denk- en doegroep voorstellen aan Jacques Collen, voorzitter van de Academie voor Streekgastronomie in Limburg.

- Samenvatting resultaten derde bijeenkomst.

- Kritische evaluatie van de geleverde voorstellen.

Volgende vergadering wordt gepland op dinsdag 12 september 2000, van 18.00 tot 20.00 uur, in lokaal F2 op de Universitaire Campus in Diepenbeek.

Aangezien we tijdens volgende bijeenkomst stap 5 van ons stappenplan uitvoeren, betekent dit dat volgende vergadering gebaseerd is op het voorlopige eindrapport. Mogen we daarom vriendelijk verzoeken om het rapport, dat $\mathrm{u}$ aan het begin van september ontvangt, door te kijken en eventuele opmerkingen, die $\mathrm{u}$ voor de vergadering wenst mede te delen, mij toe te sturen ?

U kunt ze richten aan :

Sluismans Raf

Universitaire Campus, Gebouw D

3590 Diepenbeek

raf.sluismans@1uc.ac.be

r.sluismans@merit.unimaas.nl 
Naar aanleiding van vorige vergaderingen, staan volgende voorstellen ter discussie :

m.b.t. samenwerkingsverbanden tussen cultuur, horeca en winkelen :

- een kwaliteitslabel voor de Hasseltse winkels, horeca, musea, al dan niet gekoppeld aan streekgastronomie

- een centrale overkoepelende vereniging die horeca, middenstand, toerisme en cultuur insluit

m.b.t. de verbondenheid tussen natuur en cultuur :

- een geïntegreerde marketingaanpak voor Hasselt onder de vorm van een streekgastronomisch-, mode-, of cultureel evenement op of bij de Groene Boulevard waarbij de hele middenstand, horeca en musea betrokken worden

- om ook de inwoners van Hasselt te betrekken bij wat eerder een geïntegreerde marketingaanpak genoemd werd, zou ieder gezin dat in Hasselt woont een exemplaar van de toeristische brochure in huis moeten krijgen. Als inwoners van Hasselt spelen zij een voortrekkersrol om de mond aan mond reclame een duwtje in de rug te geven. Het spreekt voor zich dat dit enkel mogelijk is als ze over de juiste informatie beschikken.

- een derde voorstel waarbij de link gelegd kan worden tussen ditmaal de cultuur van zakenmensen en de dingen die Hasselt te bieden heeft, is de taxi-chauffeurs onder een of andere vorm een introductie te bieden in de toeristische bezienswaardigheden van Hasselt. Zoals op vorige vergadering aangegeven, worden taxi-chauffeurs nogal eens geconfronteerd met de vraag vanuit zakenmensen om hen snel even langsheen de belangrijkste bezienswaardigheden te loodsen.

m.b.t. het verhogen van mobiliteit :

- op verscheidene plaatsen in de stad plattegronden voorzien in vorm van een scheursysteem (naar Scandinavisch model) waar bezoekers van Hasselt zelf een kaart kunnen afscheuren

- het functioneren van het $\mathrm{P} \& \mathrm{R}$ systeem verbeteren door stiptere en regelmatigere transporten van en naar de stad 
Aanvullend op de bemerkingen, door de groep geformuleerd op vorige bijeenkomsten, kwamen volgende aandachtspunten naar boven.

\section{Kwaliteitslabel :}

- $\quad$ het gevaar van werken met labels is dat je weet waar je begint, maar niet waar je eindigt

- $\quad$ er wordt aangeraden om te kiezen voor een andere benaming en een andere insteek voor dit voorstel : minder elitair en met meer draagkracht

- $\quad$ er wordt voorgesteld een kwantiteitslabel te introduceren : een label dat wijst op de aanwezigheid van een of meer aspecten waar Hasselt voor staat, dit kan voor het ene café betekenen dat er drie Hasseltse jeneversoorten geschonken worden terwijl het voor het ander café betekent dat er zowel Hasseltse speculoos, Hasseltse koffie als een Hasseltse jenever op de kaart staan

- toch is het ook bij het kwantiteitslabel belangrijk dat er voldaan moet worden aan een aantal aspecten, wil men het logo behouden

- $\quad$ een ander voorstel, aansluitend op het kwantiteitslabel is te werken met een aantal pictogrammetjes die op de etalage gekleefd worden : ieder van de pictogrammetjes wijst dan op de aanwezigheid van een of meer van de karakteristieke eigenschappen van Hasselt

- dezelfde pictogrammetjes kunnen dan weer voorkomen in de restaurantgids of de stadsgids

- $\quad$ onderliggend idee moet zijn dat Hasselt een aantal eigenschappen van zichzelf promoot

Handelsvereniging :

- de eerdergenoemde handelsvereniging moet gezien en georganiseerd worden als een aanspreekpunt waar een aantal mensen te vinden zijn die bereid zijn om samen te werken en initiatieven te lanceren

- $\quad$ kleine initiatieven genieten de voorkeur : gericht en beperkt in tijd, een voorbeeld is erwtensoep te koop in de winter

- de organisatie van een handelsvereniging dient te bestaan uit een kleine groep mensen die vertrouwen hebben in de mensen van de administratie van de stad. Men verkiest te beginnen met een kleine groep 'believers', een sterke kern van mensen die dingen doen waarbij gewerkt kan worden op basis van mensen die andere mensen direct aanspreken als partner in een of ander initiatief. Het is niet zo dat iedereen altijd overal bij betrokken moet worden

Aangezien tijdens deze sessie enkel gediscussieerd werd over het Hasselts label en het op te richten samenwerkingsverband, volgt na deze vergadering een reeks van diepte-interviews met de actieve deelnemers van de denk- en doegroepen, opdat eenieders opmerkingen meegenomen kunnen worden bij de formulering van het voorlopige eindrapport dat als basis zal dienen voor volgende bijeenkomst. 
1.5.6 Deelnemerslijst.

\begin{tabular}{|c|c|}
\hline Zygmund Krzywania (*) & Tourisme Hasselt \\
\hline Marc Volckaerts $(*)$ & Tourist Tram \\
\hline Willy Maes (*) & Tourist Tram \\
\hline Sabine Maldoy & Inwoonster \\
\hline Michel Philtjens (2p) & Rederij Limburgia \\
\hline Odette Buntinx & De Lijn Limburg \\
\hline Willy Smeets (*) & Fietstoerisme Hasselt \\
\hline Jeanine Michiels $(*)$ & Inwoonster \\
\hline Erik Hox $(*)$ & Hasseltse Zelfstandige Ondernemers \\
\hline Paul Vos & Stedelijk Domein Kiewit \\
\hline Marleen Devogelaere & Inwoonster \\
\hline Alida Vanholst & Herk en Mombeek \\
\hline René Geladé & Cultureel Centrum Hasselt \\
\hline Sam Sluismans $(*)$ & Vooronderzoek \\
\hline Marcel Vanreppelen (*) & HTM taxi \\
\hline Claire Lelièvre & Japanse Tuin \\
\hline Caroline Lahou & Holiday Inn \\
\hline Ivo Konings & Toegankelijkheidsbureau \\
\hline Wim Gommers & Bibitor \\
\hline Jaak Vandeweyer $(*)$ & Trefcentrum Boulevard \\
\hline Ignace Schoepen & Natuurreservaten \\
\hline Walter van Soest & Limburg Toerisme \\
\hline Johan Swennen & Literair Museum \\
\hline Jean-Pierre Swerts $(*)$ & Toerisme Hasselt \\
\hline Carol-Ann Vandeput & Congresbureau Hasselt-Genk \\
\hline Ann Vandeput & Nationaal Jenevermuseum \\
\hline Jos Coteur & Wandelroutes \\
\hline Philip Delvaux & Verenigde Handelaars Hasselt \\
\hline Guido Quintens & Verenigde Handelaars Hasselt \\
\hline Inge Marchal & Stadskernmanager \\
\hline Patrick De Groote (*) & Projectcoördinator \\
\hline Raf Sluismans & Projectvoorzitter \\
\hline Jan Yperman $(*)$ & Schepen voor Toerisme \\
\hline
\end{tabular}




\title{
1.6 Bijlagen
}

1.6.1 Label: Voorbeeld Roskilde Stjernebutikker

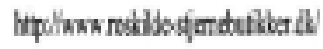

\section{ROSKLDE STJURNEBUTKKKER}

Her er kunden $\mathrm{i}$ centrum

Openingspagina van de Roskilde

'Ster-winkels':

Vanaf hier kan men

doorlinken naar een

interactieve

rondleiding, een lijst

van de deelnemernde

winkels, een

activiteitenkalender,

een reactie-pagina en

een parkeergids.

De hierna volgende

pagina's zijn

respectievelijke

afdrukken van de

Gisieg

Roshilde Stemebutikker

.$\$ 5$ speciabutikser byder velkommen il

Roskilde.

\section{Eptr}

Buther

Reaplin

Saritios

P.Guide

Pis \& Ros

Roshilde Fortrugarpanel

Er du athr fortongen? - sab las mere her.

\section{Gavekort}

Sternebutheme tibyder et smi.ht gavekot der kan hobes hos Roskide Bark IAlgate. Gavelortet kat indases i santige 95 Sijemeb_tiker.

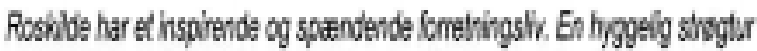

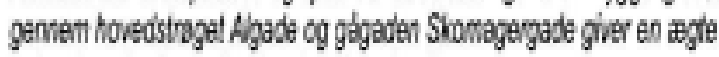

Sternetibud oplevelse af et hyggeight darsh hobstadsmiv.

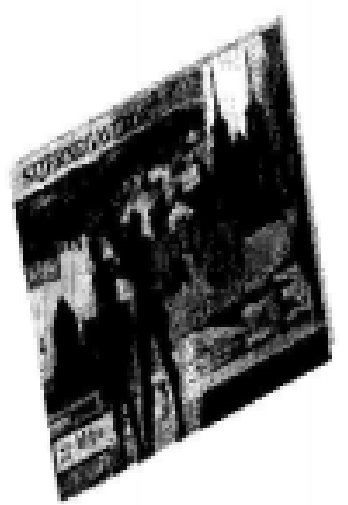

webpagina's

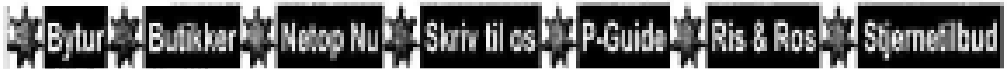

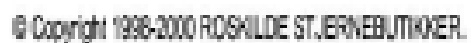

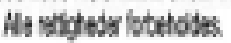

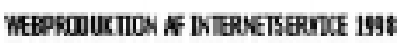


Het begin van de interactieve rondleiding langsheen de handelszaken van Roskilde.
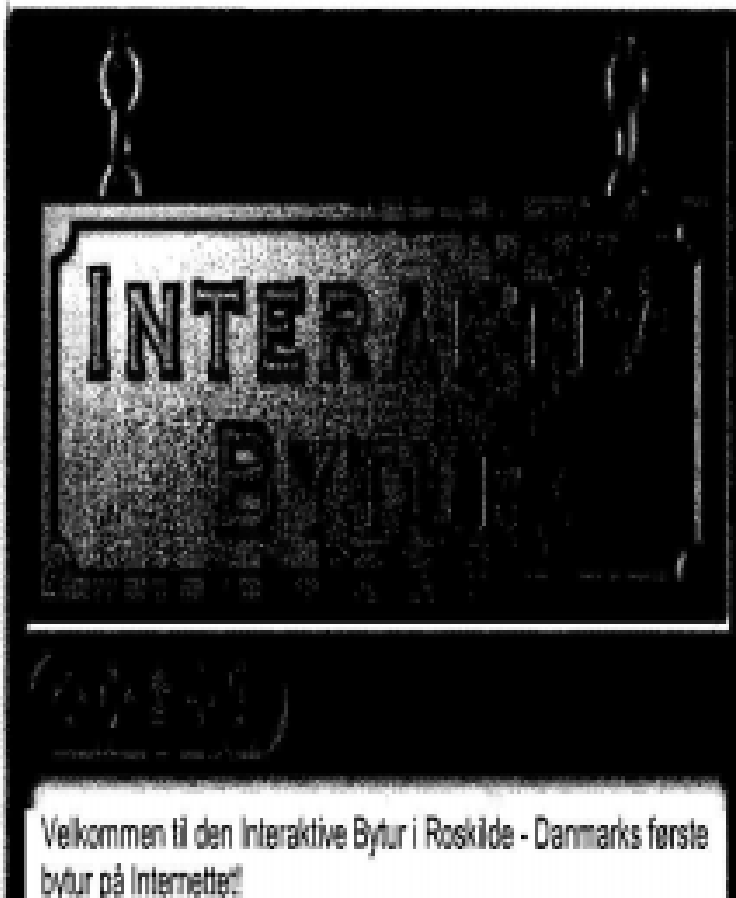

byur pá Internettet:

Byuren er nem al bruge - du klikerer blơ pá biledet i skazmen eler pá teksien under skzormen.

Du kan gad en tur i bjen og cogsá komme ind i byers forehninger hvor du blardi andei se pa gose floud.

Poigig god fomajelse.

Begynd het

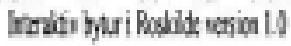

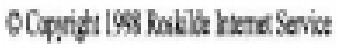




\section{ROSKILDE STJERNEBUTIKKER}

Her er kunden i centrum

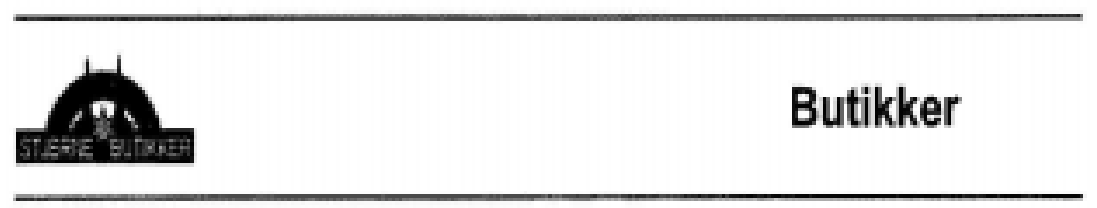

Velkommen hos Roskide Sjernebutikker, du har fra derne side mulighed for vod at kikke pal en af de nederstbende overskiffer mulighed for at bessge vores medlemmers hjemmesider.

\section{B Alizbefisk/sta \\ B Liste eftar adresse \\ Branche gursin:}

Du har her mulghed for at soge mellem Roskilde Stejnebuthkers medlemmer...

Indast et segeord i febet henunder, seger du f.eks, nye briler, skriv ordet i zriler" i fellet og tyk ssg.

Sog:
Ale ord
$7 \longdiv { 5 0 0 }$

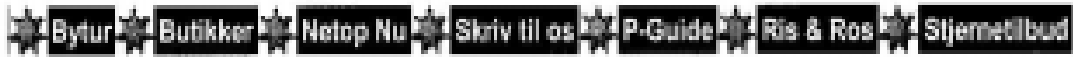

\section{Bente Dahl}

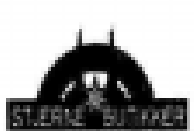

Steden 2

4000 Rnskide

Telefion: 46352250

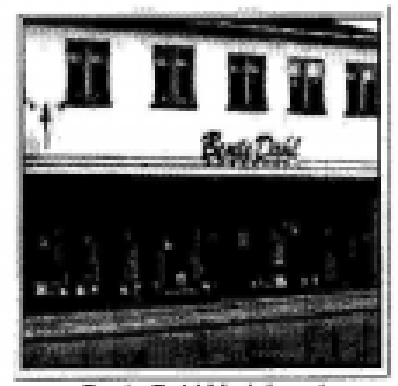

Benfe Dahy Modehusef

Staden 2
Bente Dahl Modahuset er medlem af Roskilde

Stjernebutikker.

Vi har at meget stort udvalg - specielt testte; til entwer lejlighed.- man kan vare sibker pa en meget god beçening af dygtige medarbejdare.

Kig ind og se dig omkring, fa inspiration i den nyeste mode, vi radgiver gerne og har altid en lille forffisknng. 
ROSKILDE STJERNEBUTIKKER

Her er kunden I centrum

Netop Nu

GARANTI - ÅBENTI ROSKILDE CITY

Mandag = Onsdag til kd. 17.30

Torsdag $\&$ fredag til k.1. 18.00

1. lordag I maneden til $\mathrm{kl} .16 .00$

Dvrige lerdage til kl. 14.00

Herudover har fiere af wores butikber udvidet soningstider.

Hammersiag med Frode Munksoard

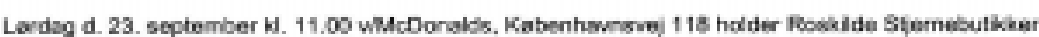
Hanmersiso med Frode Murksgibn

Kom tal auktion og gar ef kup. Her er ak fna kekkener, biles, bernefedselsdsge, "Dinner 8 Bowr. mablev, vanrkloj $\mathrm{mm}$

Vareme kan besigtipes fra mandog d. 18. september hos:

AutuBersen, Jagen C. Nieisen Mebier, Kvick Kabkencenter, McDonsids. DanBow og Silvan.

Fematjernet Vinfestivel

Onsdag d. 4 obsober hokder Roskide Stemebutikiker femstemet vinfestival pa Scandic Hotei kd. 1900 .

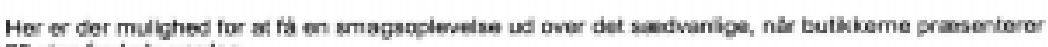
Do vine fra hele verden.

Bletame kattar $100 \mathrm{kr}$. eg kan kabes hes de detagende buskver: Fothx, Kveskly, Strandberg og Den Frarake Virhandel.

\title{
ROSKILDE STJERNEBUTIKKER
}

\author{
Her er kunden i centrum
}

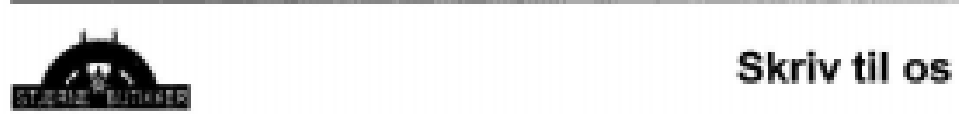

$<\%$ font\%>Ved geacrelle sparesmall:

K\%font\%-Ved tekniske sporgsmal:
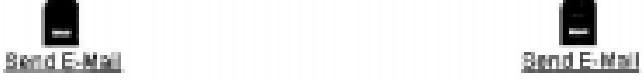

Du er alsd veikormmen 51 at skrive bi Reskibe Sjemebutkker.

Det kan vare du har kommentarer ill forskel log tho i byen, oode ideer eler andet.

Du kan naturigris ocal sparge bil produkter, varer og priser fra de enkehe medemmer of Roskide Siemebutikiker.

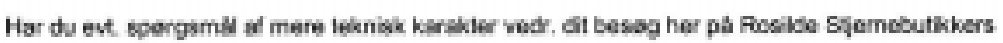
hiemmesider.

kin du ogsa fa svar pa dette.

Der er alts tre muligheder:

1. Poskide Stjernebutkkers konker. Du kibker pâ cenre side under generele spargsmal.

2. Tekniske spergamal, Du kikker pas darne side under tekniske sporgsmal.

3. Mediemmerne. Ga ti dot enkete medlems hjemmeside og klk der. 


\section{ROSKILDE STJERNEBUTIKKER}

Her er kunden i centrum

\section{P-Guide}

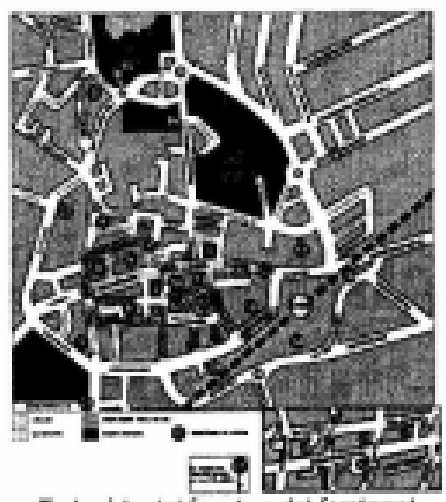

Tryk pe kortet for at se det forsterret.

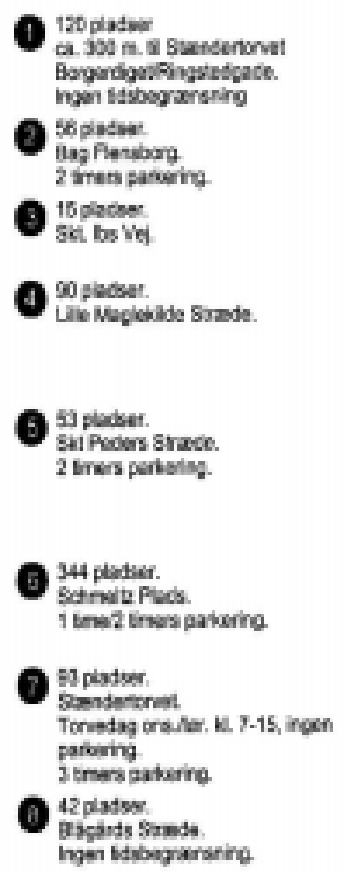

\begin{tabular}{|c|c|}
\hline 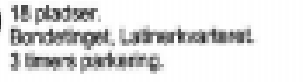 & $\begin{array}{l}13 \text { piaisar. } \\
\text { Lbielonsosde. } \\
2 \text { triess paskerine }\end{array}$ \\
\hline 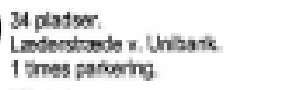 & $\begin{array}{l}60 \text { pladse:. } \\
\text { Ny Daxpode. } \\
\text { hyen tessoegrerening }\end{array}$ \\
\hline $\begin{array}{l}63 \text { glatser. } \\
\text { Ladersirode x. Roskide Bark } \\
2 \text { Ines gabering }\end{array}$ & 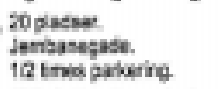 \\
\hline 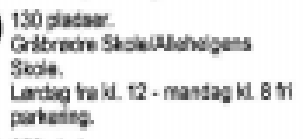 & 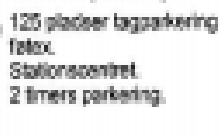 \\
\hline 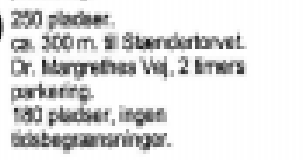 & $\begin{array}{l}\text { Parvaing. Mbortsen s } \\
\text { Holn. }\end{array}$ \\
\hline 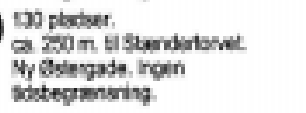 & $\begin{array}{l}\text { Parkelang, Javgen C. } \\
\text { Nosen. }\end{array}$ \\
\hline 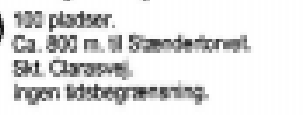 & Parketres, Sivas UK. \\
\hline 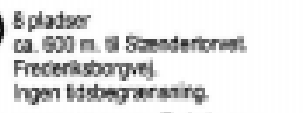 & $\begin{array}{l}45 \text { platsw } \\
\text { Katertioveswed } 118 .\end{array}$ \\
\hline Ruside Egrene Turittunsa & 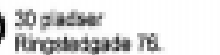 \\
\hline
\end{tabular}


1.6.2 Informatie en vorming: Voorbeeld Köln Taxi-guide 
1.6.3 Kaartensysteem: Voorbeeld Zweden, Chefen and Chefen
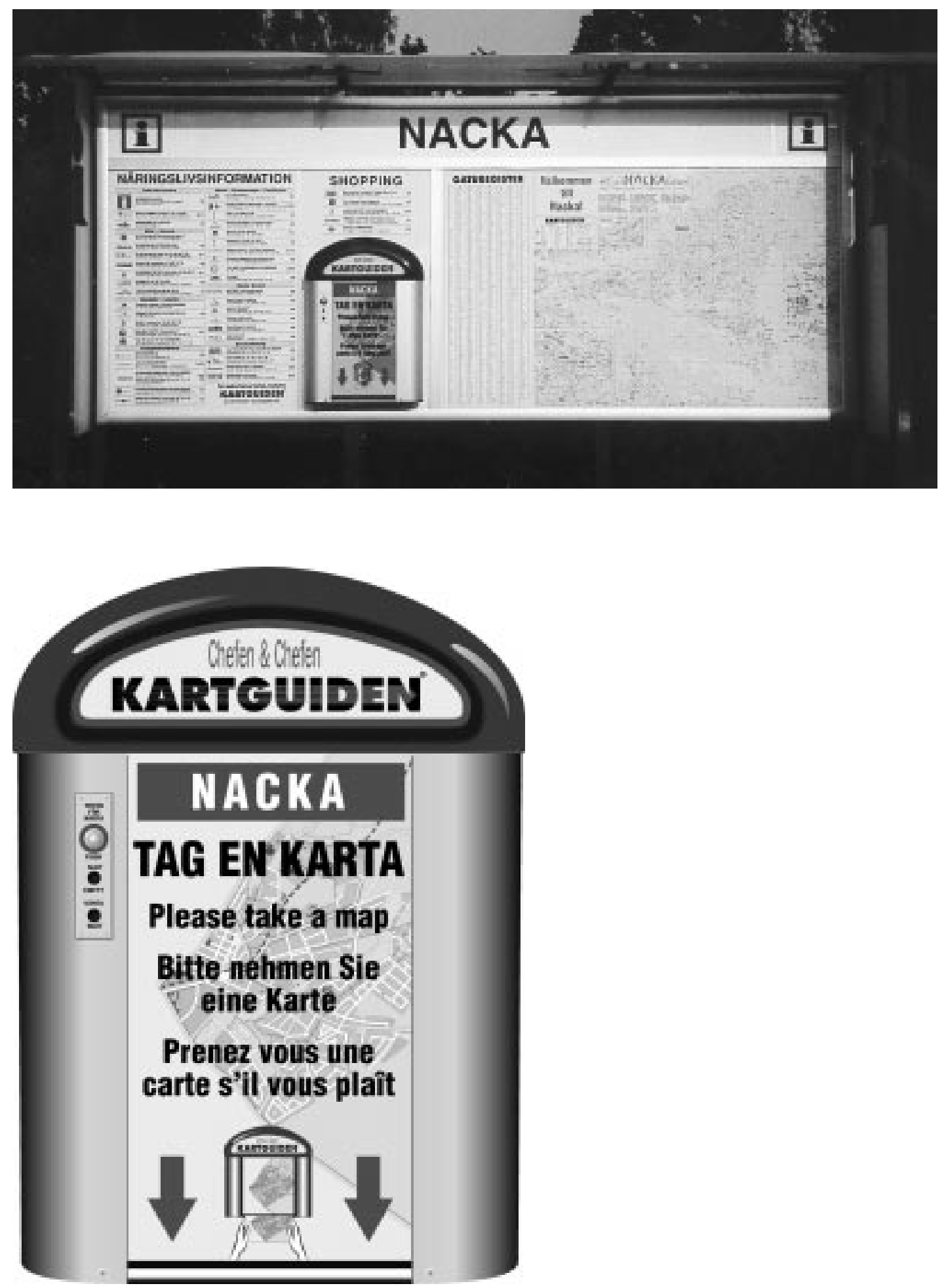


\subsection{Bibliografie}

Boerjan, P en Kochanek, S

(1995). TOBOS: Toeristische Overheid Bedrijfsleven en Onderwijs in samenwerking: "Relatie tussen Cultuur en Toerisme", Brussel, 100 p

De Groote, P (eindred.)

(1999). Project Toerisme Hasselt 2000, Onderzoeksrapport Toerisme 1999/1, LUC, Diepenbeek, 5 delen, 586 p.

De Groote, P (eindred.)

(1999). Project Toerisme Hasselt 2000, in de reeks TOERACTUA 1999/2, LUC, Diepenbeek, 41p.

Flikweert, A.J. en Gorter, L.P..M

(2000). "Gemeenten moeten evenementen stapsgewijs opzetten" in Recreatie en Toerisme, februari 2000, pp 14-15

Go, F.M.

(1999). "Samenwerken aan toekomstige belevingseconomie van binnenstad: van visie naar actie" in Recreatie en Toerisme, juli-augustus 1999, pp 10-13

Jansen-Verbeke, M. e.a.

(2000). "Cultuurtoerisme en Stedelijke revitalisatie" in de reeks Leuvense Geografische Papers nr. 11, ISEG, KU Leuven, Heverlee-Leuven, 254 p.

Provincie Limburg, 4e directie - cel middenstand

(2000). Onderzoeksrapport: "Markten in Limburg", wettelijk depot: D/2000/5857/16, pp 76-77, 80-82 
Roovers, W.M.J.M.

(1999). "Stad kan toerisme goed gebruiken" in Recreatie en Toerisme, april 1999, pp 6-9

Schuitemaker, I

(2000). "Aantrekkelijk voor de bevolking, aantrekkelijk voor toeristen" in Recreatie en Toerisme, maart 2000, pp 6-9

te Riele, $\mathrm{H}$.

(2000). "Toeristische trekkers van eerste orde: Evenementen maken Deventer tot een toeristische stad" in Recreatie en Toerisme, februari 2000, pp 6-9 